\title{
Larval trematodes infecting the South-American intertidal mud snail Heleobia australis (Rissooidea: Cochliopidae)
}

\author{
Pilar Alda ${ }^{*}$ and Sergio R. Martorelli ${ }^{1}$ \\ ${ }^{1}$ Centro de Estudios Parasitológicos y de Vectores, Consejo Nacional de Investigaciones Científicas y Técnicas - Universidad Nacional \\ de La Plata (CCT La Plata - CONICET - UNLP), Calle 2 Nro. 584, 1900 La Plata, Buenos Aires, Argentina
}

\begin{abstract}
Larval trematodes infecting the snail Heleobia australis (Cochliopidae) from the Bahía Blanca estuary, Argentina were surveyed for two years. A total of 7,504 snail specimens was dissected and the larval stages of 15 different trematodes were recovered and examined morphologically. These larvae included four species that had previously been reported from H. australis in Brazil, Uruguay, and Argentina: the heterophyid Ascocotyle (Phagicola) longa and the microphallids, Maritrema bonaerense, Maritrema orensense, and Microphallus simillimus. Three other species, the echinostomatid Stephanoprora uruguayensis, the microphallid Levinseniella cruzi, and the psilostomid Psilochasmus oxyurus are reported here for the first time as parasites of H. australis. Eight other trematodes found in H. australis are described and placed in the appropriate superfamilies, families or genera (Cryptogonimidae, Apocreadiidae, Aporocotylidae, Notocotylidae, Haploporidae, Renicolidae, Himasthla, and Renicola). The prevalence of the trematode taxa infecting $H$. australis in the Bahía Blanca estuary was low $(<3 \%)$ with a single exception (M. simillimus; $>20 \%$ ). Microphallidae were the richest and the most prevalent family, probably because of the high abundance of crabs - the second-intermediate hosts of certain microphallid species - and the considerable diversity of gulls. Here we compare the parasite assemblage found in the H. australis from Bahía Blanca estuary with other parasite assemblages infecting Heleobia spp. and other rissooids from the rest of the world.
\end{abstract}

\section{Keywords}

Bahía Blanca estuary, Digenea, gastropods, larval stages, Trematoda

\section{Introduction}

Heleobia australis (d'Orbigny, 1835) is a small marine snail that comprises a major biotic component of the fauna in estuaries (De Francesco and Isla 2003) from Rio de Janeiro (Brazil) to San Antonio Oeste (Argentina) (Gaillard and Castellanos 1976). The genus Heleobia Stimpson, 1865, a member of the family Cochliopidae Tryon, 1866 , is phylogenetically close to the cosmopolitan family Hydrobiidae Stimpson, 1865 (Wilke et al. 2001). Both families resemble each other in anatomical features as well as in ecology and biology in general (De Francesco and Isla 2004) and have been reported as intermediate hosts of many species of trematodes (Deblock 1980, Etchegoin 1997).

Larval trematodes infecting $H$. australis have been reported in Brazil, Uruguay, and Argentina. To date, seven trematode species have been recorded (Etchegoin 1997, Etchegoin and Martorelli 1997, Carnevia et al. 2004, Simões et al. 2008, 2009, 2010, Alda et al. 2010, 2013): four microphallids [Mi- crophallus simillimus (Travassos, 1920); Microphallus szidati Martorelli, 1986; Maritrema bonaerense Etchegoin et Martorelli, 1997; and Maritrema orensense Cremonte et Martorelli, 1998], two heterophyids [Ascocotyle (Phagicola) longa Ransom, 1920 and Pygidiopsis macrostomum Travassos, 1928], and a cryptogonimid (Acanthocollaritrema umbilicatum Travassos, Freitas et Bührnheim, 1965). Eleven other trematodes have been described but not identified to the species level (Etchegoin 1997). Castro et al. (2006) found larval trematodes parasitizing $H$. australis in Uruguay but provided no formal descriptions or species assignments.

Our aim was to study the larval trematodes that infect H. australis in the Bahía Blanca estuary (Argentina); where $H$. australis, the most abundant benthic species, is the only cochliopid snail present (Elías et al. 2004). We provide here the first description of previously uncharacterized larval trematodes and place them in taxonomic superfamilies or families and sometimes genera. We also provide the redescription of the sporocyst and metacercaria of M. simillimus and add 
prevalence data along with comments on the diagnoses and life cycles of all the trematodes reported for $H$. australis.

\section{Materials and Methods}

Snails were collected at low tide on 16 sampling dates from May 2006 through July 2008 from the intertidal of the Bahía Blanca estuary, Argentina. In total, 7,504 specimens were recovered from three sites within the estuary (Site 1: $38^{\circ} 44^{\prime} \mathrm{S}$, $62^{\circ} 22^{\prime} \mathrm{W}$; Site 2 : $38^{\circ} 46^{\prime} \mathrm{S}, 62^{\circ} 18^{\prime} \mathrm{W}$; and Site 3 : $38^{\circ} 51^{\prime} \mathrm{S}$, $62^{\circ} 07^{\prime} \mathrm{W}$ ). The snails were kept in an aquarium in the laboratory until parasitological examination. We kept the snails individually in 2-ml vials under an 8-h-light to 16-h-dark lighting regime for three consecutive days at room temperature to promote cercarial emergence. Cercariae were studied alive under a compound microscope before being fixed in hot $10 \%(\mathrm{v} / \mathrm{v})$ formaldehyde. For microphallids and heterophyids, we used neutral red to stain the penetration gland cells.

All snails were dissected to check for the presence of prepatent infections and examine the intramolluscan stages and metacercariae. However, the first intramolluscan stage the mother sporocyst - was never observed.

The metacercariae were placed in small Petri dishes containing saline solution for $48 \mathrm{~h}$ at $39-40^{\circ} \mathrm{C}$ to facilitate excystment. Metacercariae of $M$. simillimus excysted without external manipulation, whereas the renicolid metacercariae could be excysted only through the use of dissection needles. The metacercariae belonging to the families Notocotylidae and Haploporidae and those of the species Psilochasmus oxyurus (Creplin, 1835) could not be excysted. Cysts and excysted metacercariae were fixed in $10 \%(\mathrm{v} / \mathrm{v})$ formaldehyde.

Drawings were made with the aid of a camera lucida. For each larval trematode described, measurements were based on specimens fixed in hot $10 \%(\mathrm{v} / \mathrm{v})$ formaldehyde solution and are expressed in micrometres as the range followed by the mean \pm sd and the number of specimens in parentheses. Overall prevalence (i.e., over all sites and through all dates) was calculated following Bush et al. (1997) for each trematode taxon except for M. orensense, M. bonaerense, and L. cruzi; where the prevalence was estimated for all three together because the similarity between those larval stages did not allow us to differentiate them until later experimental infections and further studies were done (Alda et al. 2013). Voucher material of the larval trematodes described here for the first time was deposited in the Helminthological Collection of La Plata Museum (MPHC) and voucher specimens of $H$. australis in that museum's Malacological Collection (MPMC 13532).

For scanning electron microscopy, larval trematodes were fixed in hot $10 \%(\mathrm{v} / \mathrm{v})$ formaldehyde without pressure, dehydrated through a series of ethanol concentrations, immersed in hexamethyldisilazane for $1 \mathrm{~min}$, and air dried at room temperature. The trematodes were mounted and coated with gold and micrographs were obtained with a Philips SEM 505 scanning electron microscope.
To locate the site of infection within the snail, some of the infected snails with patent infections were fixed in Bouin's fluid for at least 10 days. The decalcified shells were then removed and the soft tissues embedded in paraffin for slicing at a thickness of 4 micrometres. The serial sections obtained were stained with hematoxylin and eosin. The sites of infection of Himasthla sp., P. oxyurus, and the apocreadiid were not determined by the procedure described above because these taxa were rare and therefore dissected in order to study the intramolluscan stages. We did not compare the larval trematodes described here with those from snails other than Heleobia. Trematodes are frequently highly specific towards their first intermediate snail host (Cribb et al. 2001), though we do assume that a single trematode species would infect snails that belong to the same genus (Hechinger 2007).

\section{Results}

Of the 7,504 specimens dissected 2,126 were infected (28\%). Table I lists the 15 different larval trematodes found in $\mathrm{H}$. australis in the Bahía Blanca estuary including the type of intramolluscan stage present, the second intermediate host, the definitive host, and the prevalence.

\section{Family Heterophyidae Leiper, 1909 Ascocotyle (Phagicola) longa Ransom, 1920 Prevalence: $0.9 \%$}

\section{Remarks}

The morphologic features of the redia and cercaria were consistent with the characteristics of Ascocotyle (Phagicola) longa. The most distinctive features of this species are the lack of setae and the possession of a cercaria with a tail with small ventro-terminal fin fold and small spine-like structure at caudal extremity; two rows of acicular spines on its anterior border and small papillae on its lateral and posterior border; seven pairs of penetration gland cells; 16 flame cells; a V-shaped excretory vesicle; and a caudal excretory duct extending into tail, bifurcating at base of tail, and opening as lateral excretory pores (Simões et al. 2010). Simões et al. (2010) first described the redia and the cercaria of $A$. (P.) longa from H. australis in Brazil, the only difference with the one found in this study being the shorter rediae (258-443 vs 470-500). This difference could be a result of different degrees of development of the rediae. Simões et al. (2010) found $A$. (P.) longa parasitizing the gonad and digestive gland, whereas we detected this species in only the gonad. Martorelli and Etchegoin (1996) and Etchegoin (1997) reported a similar larval stage in H. australis and Heleobia conexa (Gaillard, 1974), which stage they named Pleurolophocercaria III. Their material, however, differs from $A$. (P.) longa in having a single row of acicular spines instead of two. Carnevia et al. (2004) and Castro et al. (2006) found $A$. (P.) longa parasitizing $H$. australis in Uruguay but provided Unauthenticated Download Date | 9/4/19 7:25 PM 
Table I. Larval trematodes infecting the snail Heleobia australis from the Bahía Blanca estuary in Argentina. Prevalence was calculated over all sites and dates. $\uparrow$ Prevalence for Maritrema orensense, Maritrema bonaerense, and Levinseniella cruzi was estimated for all three together

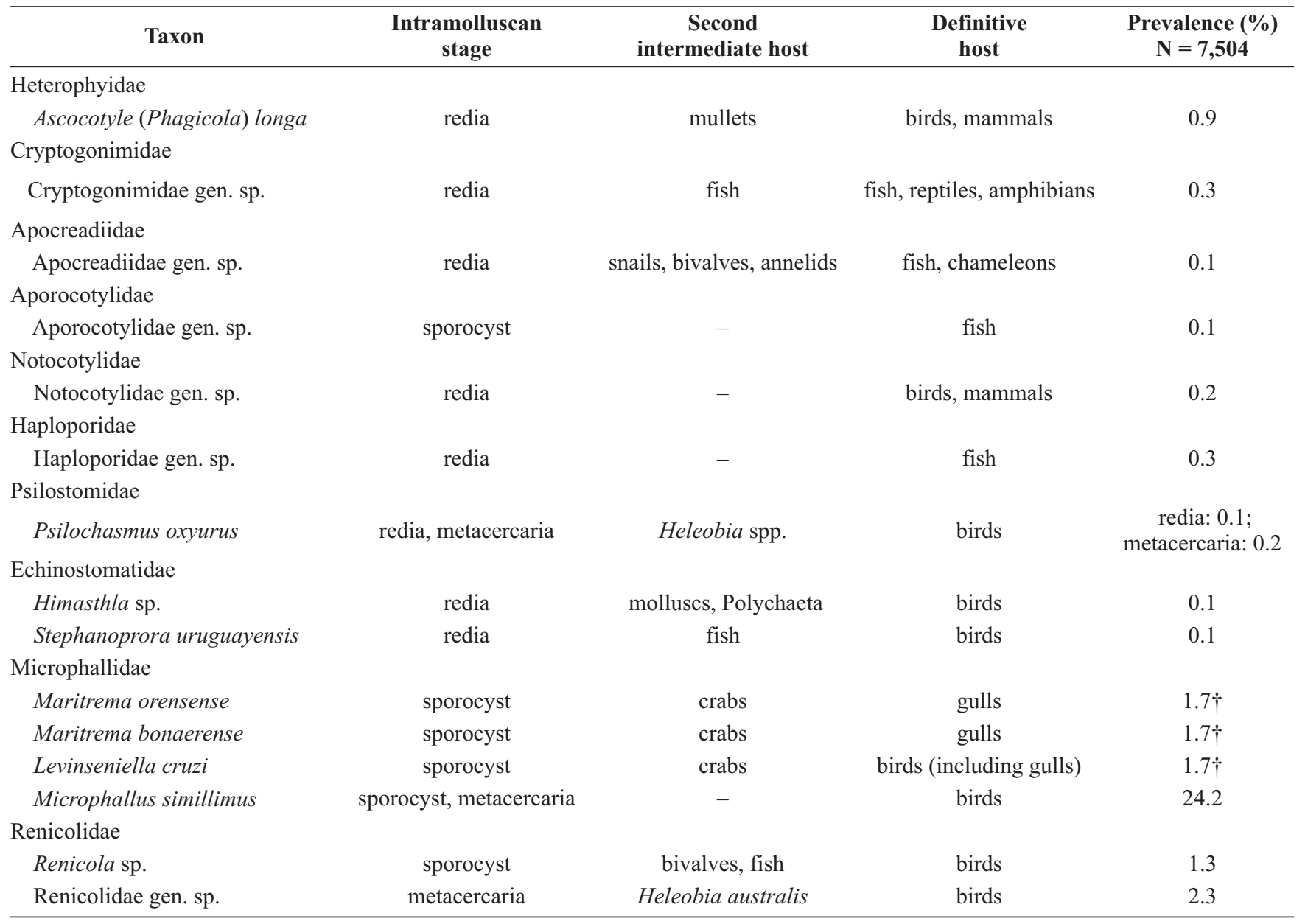

no formal description. Simões et al. (2010) elucidated the life cycle of this widespread species; which uses mullets as second-intermediate hosts and birds and mammals, including man, as definitive hosts. Ascocotyle (P.) longa is one of the causative agents of heterophyiosis, an emerging fish-borne disease of humans, contracted by the consumption of raw mullet (Martorelli et al. 2012). Recently, metacercariae of $A$. (P.) longa were found in mullets from Samborombón Bay, located $550 \mathrm{~km}$ northeast of the Bahía Blanca estuary (Martorelli et al. 2012). The present study, along with the reports of Martorelli et al. (2012) and Santos et al. (2013), represents a warning about the potentially major impact of this parasite on public health in South America. We assume that the life cycle of $A$. (P.) longa in the Bahía Blanca estuary would be as described in Brazil since mullets have been reported in the estuary (López Cazorla 2004). This record is the southernmost one of $A$. (P.) longa.

\section{Family Cryptogonimidae Ward, 1917}

\section{Cryptogonimidae gen. sp.}

Voucher material: MPHC 6555.

Prevalence: $0.3 \%$

Redia (Fig. 1A)
Found in gonad of $H$. australis. Body sac-like, without appendages, $240-597(379 \pm 138, \mathrm{n}=11)$ long and 87-153 $(124 \pm$ $24, \mathrm{n}=10$ ) wide, filled with germinal balls and up to 20 developing cercariae. Pharynx 12-37 $(29 \pm 6, \mathrm{n}=12)$ long and $20-40(27 \pm 6, n=20)$ wide, short caecum with colorless matter.

\section{Cercaria (Figs 1B-C; 2A)}

Body pyriform, 153-214 (187 $\pm 17, \mathrm{n}=20)$ long and 51$110(83 \pm 17, \mathrm{n}=20)$ wide. Tegument around oral sucker covered with spines. Tail longer than body, 331-450 (398 \pm $35, \mathrm{n}=11)$ long and 23-36 (30 $\pm 4, \mathrm{n}=13)$ wide, deeply attached into pronounced subterminal socket, with many muscular fibres and a dorsoventral fin covering entire anterior extension and the two posterior thirds of ventral extension of tail. Pair of eyespots located posterior to oral sucker, $7-15(12 \pm 2, \mathrm{n}=20)$ long and 6-29 $(19 \pm 6, \mathrm{n}=20)$ wide. Oral sucker terminal, with 7 acicular spines on its anterior border (Fig. 2A), 19-38 (31 $\pm 5, \mathrm{n}=17)$ long and 24-33 $(28 \pm 3, \mathrm{n}=17)$ wide. Ventral sucker, pharynx, and intestinal caeca not developed. Seven pairs of penetration gland cells at mid-body arranged in 2 pairs of rows $(3+4)$; ducts 
A
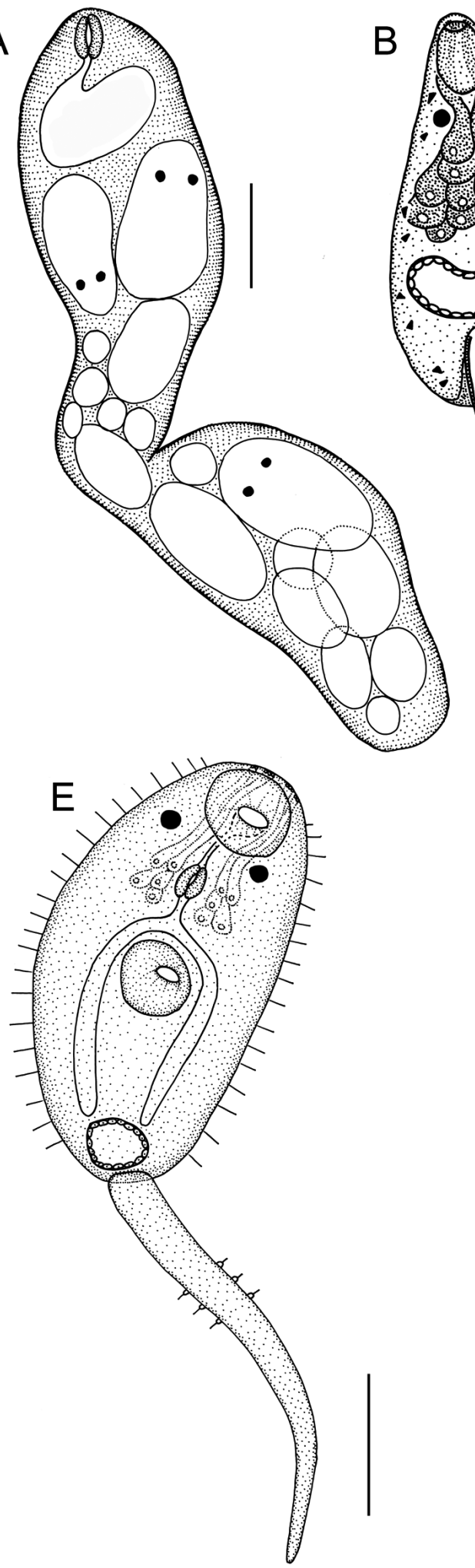
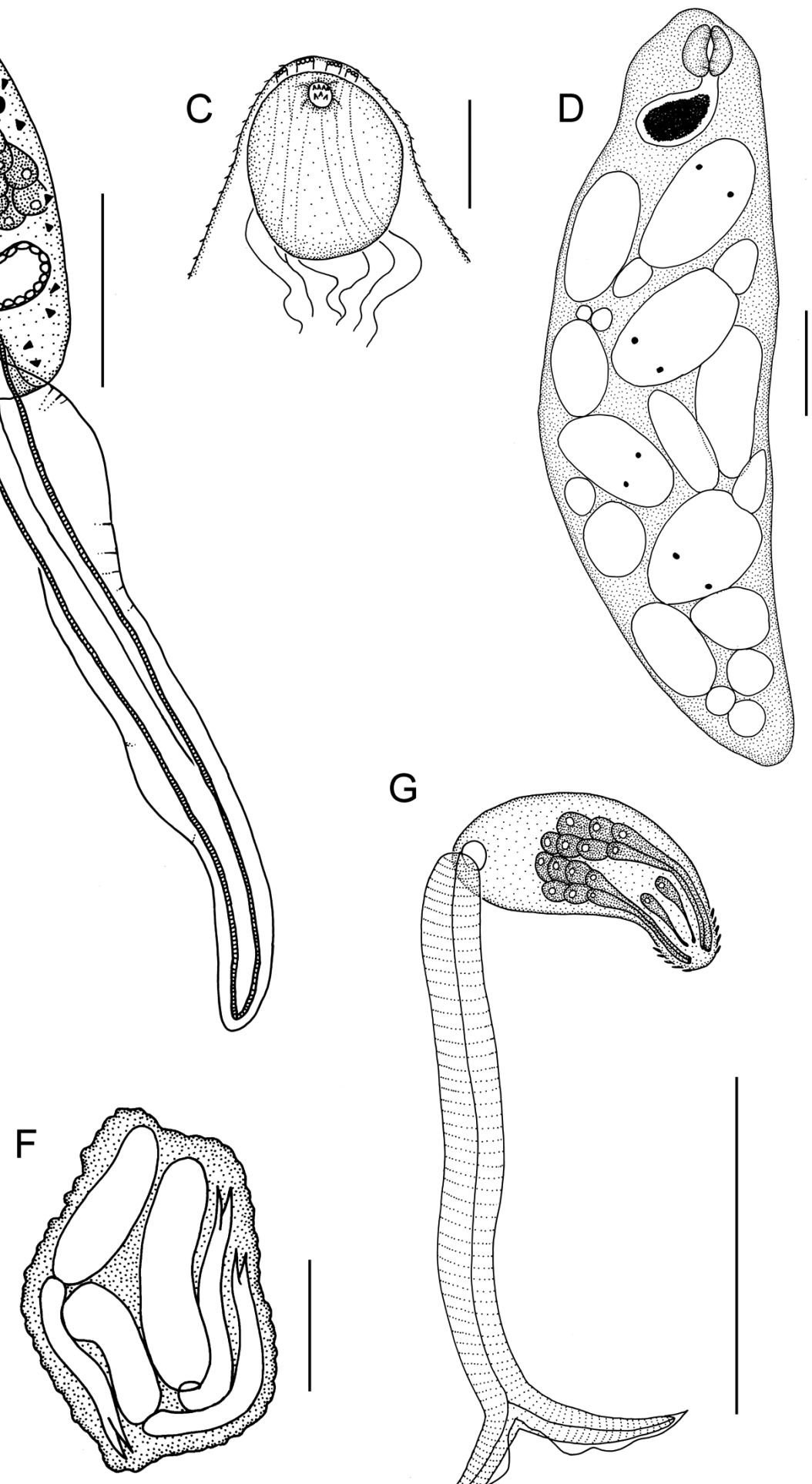

G

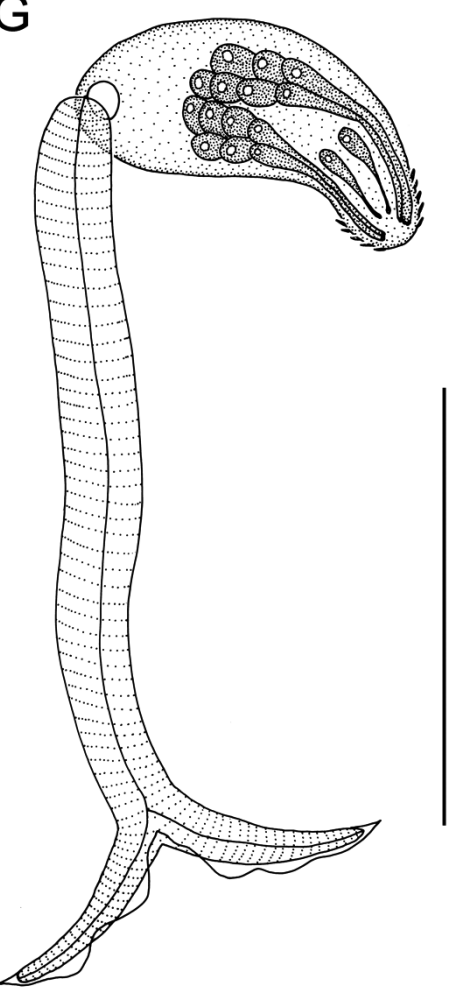

Fig. 1. Line drawings of the larval trematodes. A-C: Cryptogonimidae gen. sp. (A: redia, B: cercaria, C: anterior part of cercaria in detail); D-E: Apocreadiidae gen. sp. (D: redia, E: cercaria); F-G: Aporocotylidae gen. sp. (F: daughter sporocyst, G: cercaria). Scale bars: A, 20 mm; B-F, $100 \mu \mathrm{m}$; G, $50 \mu \mathrm{m}$ 

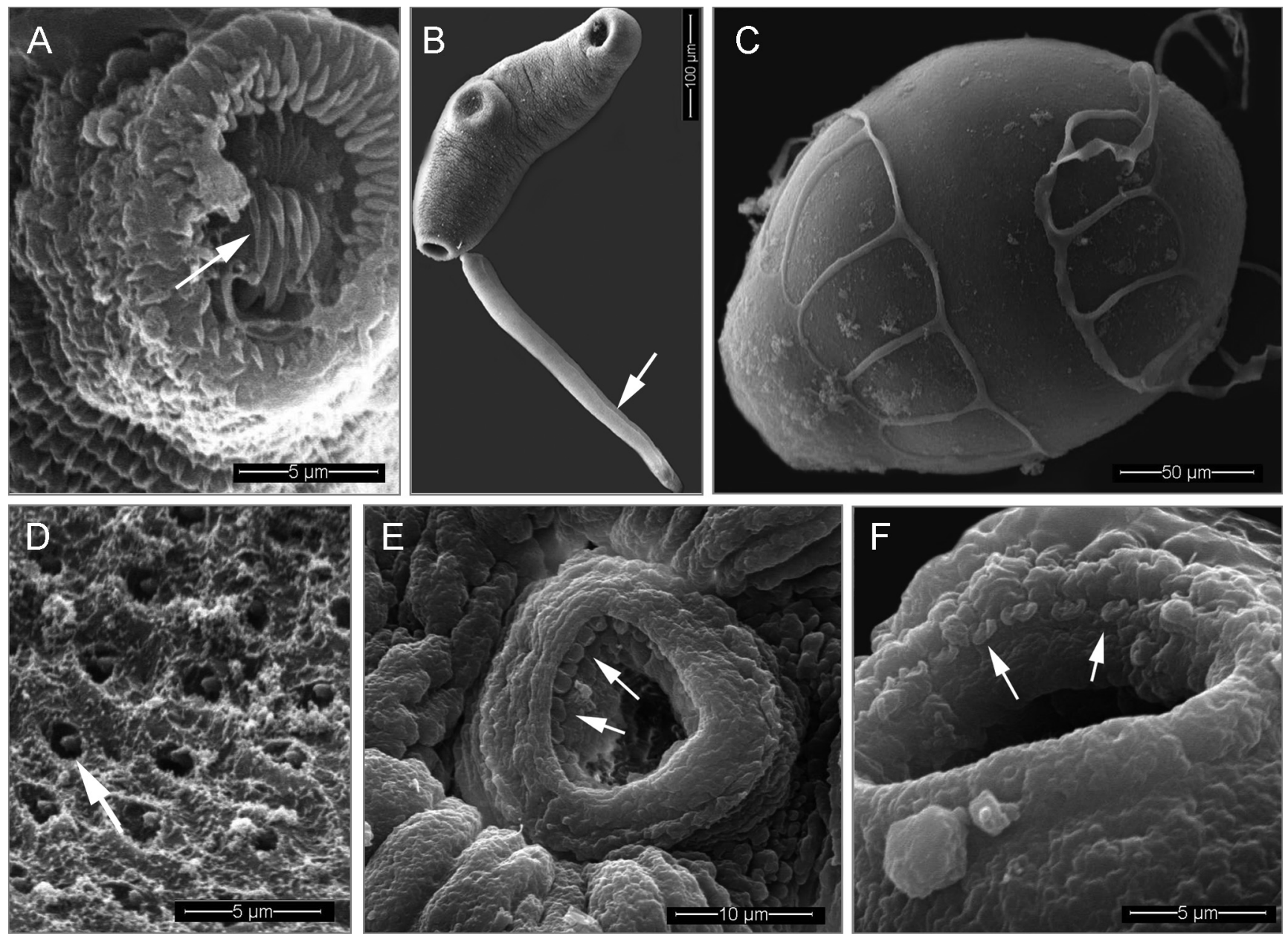

Fig. 2. Larval trematodes under scanning electron microscopy. A: Cryptogonimidae gen. sp., anterior part of cercaria showing acicular spines and tegument covered with spines; B: Haploporidae gen. sp., cercaria showing socket where tail is attached and dorsal groove of tail; C: metacercaria showing lateral filaments of the outermost wall; D: Himasthla sp., tegument with small spines located in holes; E-F: Stephanoprora uruguayensis (E: ventral sucker showing flattened spines around opening, F: oral sucker showing the flattened spines on anterior border)

group at eyespot level, pass oral sucker in 2 groups, and open via 4 groups of $3,4,4$, and 3 outlets on anterior extremity (Fig. 1C). Excretory vesicle V-shaped, with thick epithelial wall. Flame-cell formula $2[(2+2)+(2+2)]=$ 16. Cercariae very motile, alternate periods of swimming and resting; during latter sink to bottom with body and tail forming a right angle.

\section{Remarks}

According to Schell (1970), a cercaria with a bilobed, thickwalled, and epithelial excretory vesicle and a dorsoventral fin and without a ventral sucker and lateral fins (pleurolophocercaria) belongs to the superfamily Opisthorchioidea Looss, 1899 comprised of the families Cryptogonimidae, Opisthorchiidae Looss, 1899, and Heterophyidae. The presence of a well developed dorsoventral fin, however, is characteristic of cryptogonimids. Three cryptogonimid species have been described from Heleobia spp. from South America: Acanthocol- laritrema umbilicatum Travassos, Freitas et Bührnheim, 1965 in H. australis from Brazil (Simões et al. 2008), Acanthostomum brauni Mañe Garzón et Gil, 1961 in Heleobia castellanosae (Gaillard, 1974) (Ostrowski de Núñez 1987), and Acanthostomum gnerii Szidat, 1954 in Heleobia parchappii (d'Orbigny, 1835) (Ostrowski de Núñez 1974, Ostrowski de Núñez and Gil de Pertierra 1991). The larval trematode described here differs from $A$. umbilicatum in having a longer body (153-214 vs 115-126), a longer tail (331-450 vs 251-294), and a larger oral sucker (19-38 $\times$ 24-33 vs 18-23 × 18-23) and from A. brauni and A. gnerii in lacking setae in the cercaria and redia and in having fewer flame cells (16 vs 36) along with a tail lacking a thick tegument but with a dorsoventral fin attached to the anterior end. Our description agrees with that of Pleurolophocercaria I by Martorelli and Etchegoin (1996) and Etchegoin (1997) based on materials from $H$. conexa and $H$. australis. Cryptogonimids encyst in fish and mature in fish as well, but also in reptiles and, though only rarely, in amphibians (Miller 
and Cribb 2008). This trematode family has not yet been reported in marine and estuarine fish from Argentina. The larval stage characterized here presumably belongs to an undescribed species that parasitizes fish in the Bahía Blanca estuary.

\section{Family Apocreadiidae Skrjabin, 1942 \\ Apocreadiidae gen. sp. \\ Voucher material: MPHC 6554. \\ Prevalence: $0.1 \%$.}

\section{Redia (Fig. 1D)}

Found in upper coils of snail body, specific organ not determined because of a lack of serial sections. Body sac-like, without appendages, 308-666 (442 $\pm 126, \mathrm{n}=10)$ long and 130-179 $(157 \pm 16, \mathrm{n}=10)$ wide, filled with germinal balls and developing cercariae. Pharynx $39-58(53 \pm 6, \mathrm{n}=10)$ long and 45-58 (53 $\pm 4, \mathrm{n}=10)$ wide; short and round caecum with dark matter, 88-185 (107 $\pm 31, \mathrm{n}=9)$ long and 58-133 $(97 \pm 24, \mathrm{n}=9)$ wide, located in first body third.

\section{Cercaria (Fig. 1E)}

Body oval, 203-327 (226 $\pm 31, \mathrm{n}=14)$ long and 110-143 $(129 \pm 11, \mathrm{n}=14)$ wide. Tegument covered with setae from mid-level of oral sucker to mid-level of excretory vesicle. Tail long, 303-350 (325 $\pm 14, \mathrm{n}=14)$ long and 30-40 (34 \pm 3 , $\mathrm{n}=14$ ) wide, armed with 3 pairs of setae at mid-length. Pair of eyespots posterior to oral sucker, $13-18(17 \pm 2, n=14)$ in diameter, 20-33 (26 $\pm 4, \mathrm{n}=14)$ apart. Oral sucker subterminal, 47-63 (52 $\pm 4, \mathrm{n}=14)$ long and 43-50 (47 $\pm 3, \mathrm{n}=14)$ wide. Ventral sucker equatorial, $37-50$ (43 $\pm 4, \mathrm{n}=14)$ long and 43-57 (50 $\pm 4, \mathrm{n}=14)$ wide. Mouth subterminal; prepharynx long; pharynx 27-37 (30 $\pm 3, \mathrm{n}=13)$ long and 17-23 (18 $\pm 2, n=13$ ) wide; oesophagus short; intestinal bifurcation anterior to ventral sucker; caeca extending to anterior end of excretory vesicle. Five pairs of penetration gland cells located laterally to pharynx; ducts pass oral sucker in 2 groups, and open anterior to oral sucker in 4 groups of 2, 3, 3, and 2 outlets. Excretory vesicle round, with thick epithelial wall. Flame-cell pattern not observed. Cercariae alternate periods of swimming and resting.

\section{Remarks}

According to Schell (1970), a distome cercaria with setae on the tail and body, eyespots, and an epithelial excretory vesicle belongs to the genus Homalometron Stafford, 1904 within the Family Apocreadiidae Skrjabin, 1942 (Cribb 2005). Three apocreadiid cercariae have been described from Heleobia spp.: Homalometron pseudopallidum Martorelli, 1986, a parasite of H. castellanosae (Martorelli 1986a); Cercaria heleobicola II, a parasite of $H$. conexa and $H$. australis (Martorelli 1989, Etchegoin 1997); and Cercaria ophtalmo- gymnocephala, a parasite of Heleobia hatcheri (Pilsbry, 1911) (Flores 2004). The larval trematode described here differs from $H$. pseudopallidum in having larger eyespots (1318 vs 8-12), fewer penetration gland cells (5 vs 6), and a smaller redia $(308-666 \times 130-179$ vs 700-1,300 × 200400); from Cercaria heleobicola II in having a narrower body (110-143 vs 162), a larger tail (303-350 × 30-40vs $225 \times 5)$, and fewer penetration gland cells (5 vs 6); and from Cercaria ophtalmogymnocephala in having a larger tail $(303-350 \times 30-40$ vs 226-228 × 17-24), a longer pharynx (27-37 vs 17-24), and more penetration gland cells (5 vs 4). The life cycles of the apocreadiids include cercariae with eyespots and setae that parasitize prosobranchs, as the form described here; these cercariae encyst in invertebrates such as snails, bivalves, and annelids (Stunkard 1964a, Martorelli 1986a, Scholz et al. 1995). The adults have been found in both marine and freshwater fish and also chameleons (Olson et al. 2003). No reports describing this family in the Argentine Sea or in the estuaries have been published. The larval stage recorded by us could belong to an undescribed species that parasitizes fish in the Bahía Blanca estuary.

\section{Family Aporocotylidae Odhner, 1912 Aporocotylidae gen. sp.}

Voucher material: MPHC 6556

Prevalence: $0.1 \%$

\section{Sporocyst (Fig. 1F)}

Found in gonad and digestive gland of $H$. australis. Daughter sporocyst sac-like, small, 83-178 $(139 \pm 41, \mathrm{n}=6)$ long and 50-122 (84 $\pm 27, \mathrm{n}=6)$ wide, containing 2-3 developing cercariae.

\section{Cercaria (Fig. 1G)}

Body ventrally curved, cylindrical, slender, translucent, small, 76-115 (88 $\pm 12, \mathrm{n}=10)$ long and 24-34 $(29 \pm 3, \mathrm{n}=$ 10) wide, without a dorsal fin. First anterior fifth densely covered with spines, arranged in several rows; first 2 rows consisting of conspicuous spines, remaining diminishing gradually in size. Tail stem muscular, striated, 159-187 (169 $\pm 9, \mathrm{n}=9)$ long and 14-17 $(14 \pm 1, \mathrm{n}=9)$ wide; furcae 53 $80(62 \pm 8, \mathrm{n}=9)$ long and 9-12 $(11 \pm 1, \mathrm{n}=9)$ wide, bearing dorsoventral fin folds. Oral sucker, ventral sucker, and digestive system absent. Eight pairs of penetration gland cells; 7 arranged in 2 groups on each side of body, ducts running forward in 2 groups and opening in groups of 3, 4, 4, and 3 outlets at anterior extremity; an additional pair of penetration gland cells located between ducts of the 7 pairs of gland cells, ducts open posterior to the 7 outlets. Excretory vesicle rounded; caudal excretory duct extends into tail, bifurcating and opening at the end of the furcae. Flame-cell pattern not observed. Cercaria very motile, alternating periods of swimming and resting. 


\section{Remarks}

The absence of suckers, eyespots, and digestive system and the presence of tail with furcae bearing fin folds, eight pairs of penetration gland cells, and two excretory pores at the end of the furcae, places this trematode in the family Sanguinicolidae von Graff, 1907 (Combes 1980), now considered Aporocotylidae (Bullard et al. 2009). Representatives of this family possess a cercaria with a well developed dorsal fin fold on the body. In some species the latter is missing e.g., in Sanguinicola davisi Wales, 1958, a parasite of snails in the USA (Combes 1980) and in Cardicola forsteri Cribb, Daintith and Munday, 2000, a parasite of polychaetes in Australia (Cribb et al. 2011). Etchegoin (1997) found a similar trematode parasitizing $H$. australis and $H$. conexa that differs from the present description in having an opaque cercarial body, three pairs of penetration gland cells, a triangular refractile structure near the anterior extremity, a shorter tail stem (30-36 vs 159-187), and shorter and narrower tail furcae $(17-18 \times 7-8$ vs 53-80 $\times 9-12)$. The present example constitutes the second formal description of a larval trematode of the family Aporocotylidae in Argentina. Aporocotylids emerge from an invertebrate host and actively penetrate fish to mature in the vascular system (Cribb et al. 2011). All known marine aporocotylid cercariae emerge from bivalves and polychaetes, whereas freshwater species emerge from gastropods (Cribb et al. 2011). We suspect that the definitive host of the form described here may thus be more in the freshwater than in the marine portion of the estuary. In Argentina a single species, Sanguinicola coelomica (Szidat, 1951), has been reported in siluriform fishes from the Río de La Plata estuary (Szidat 1951, Lunaschi 1985, Avendaño de Mac Intosh and Ostrowski de Núñez 1998). The last authors also mentioned the presence of an aporocotylid parasitizing $H$. parchappii but provided no description of this form. The larval stage described here may belong to $S$. coelomica or to some as-yet-undescribed aporocotylid.

\section{Notocotylidae Lühe, 1909 \\ Notocotylidae gen. sp.}

Voucher material: MPHC 6553.

Prevalence: $0.2 \%$.

\section{Redia (Fig. 3A)}

Found in digestive gland and gonad of $\mathrm{H}$. australis. Body saclike, without appendages, 295-660 (503 $\pm 129, \mathrm{n}=13)$ long and 110-240 (186 $\pm 47, \mathrm{n}=13)$ wide; pharynx 25-67 (49 \pm $13, \mathrm{n}=13)$ long and 20-57 (40 $\pm 10, \mathrm{n}=13)$ wide; intestinal caecum located in first half of body, contains dark matter.

\section{Cercaria (Fig. 3B)}

Monostome, triocellate cercaria. Body oval, strongly pigmented, brownish, with abundant cystogenous gland cells,
$347-483(419 \pm 39, \mathrm{n}=11)$ long and $137-213(176 \pm 24, \mathrm{n}=$ 11) wide. Tail simple, cylindrical, with blunt end and with 2 rows of caudal bodies, $270-417(334 \pm 48, \mathrm{n}=10)$ long and $37-70(62 \pm 9, n=10)$ wide. Three eyespots arranged in triangle present near anterior extremity; lateral eyespots with pigment dispersed nearby, $12-27(17 \pm 4, \mathrm{n}=9)$ in diameter, anterior to intestinal bifurcation; median eyespot posterior to oral sucker, smaller, not developed in younger cercariae. Pair of adhesive pockets situated at posterior extremity. Oral sucker subterminal, 33-63 $(42 \pm 9, \mathrm{n}=10)$ long and 27-47 $(41 \pm 5$, $\mathrm{n}=10$ ) wide. Ventral sucker absent. Mouth subterminal, pharynx absent, oesophagus bifurcates at level of lateral eyespots into 2 intestinal caeca reaching close to anterior border of excretory vesicle. Two primary excretory ducts, anteriorly passing between lateral-eyespots, expanding anterolaterally, and uniting at level of median eye, posteriorly opening into small, round excretory vesicle. Primary ducts filled with dense spherical granules. Caudal excretory duct enters tail. Excretory pore, flame-cell pattern, and genital primordia not observed. Cercaria matures outside redia inside snail. Once emerged, cercaria swims and encysts on hard substrates (found on shell and operculum of snails).

\section{Metacercaria (Fig. 3C)}

Cyst opaque, sub-spherical, $153-190(169 \pm 11, \mathrm{n}=10)$ in diameter, with 2 layers, inner layer $3-7(5 \pm 2, n=9)$ thick, outer layer $7-13(10 \pm 3, n=9)$ thick.

\section{Remarks}

The absence of a ventral sucker and the presence of abundant cystogenous gland cells, eyespots, adhesive pockets, and primary excretory ducts united anteriorly indicate that this form may belong to the families Notocotylidae or Pronocephalidae Looss, 1899 (Schell 1970). According to Yamaguti (1975), however, the cercariae of the latter family possess a head collar. Three notocotylid cercariae have been described from Heleobia spp.: Catatropis hatcheri Flores et Brugni, 2006, a parasite of $H$. hatcheri (Flores and Brugni 2006); Cercaria littoridinae, a parasite of $H$. parchappii (Szidat and Szidat 1961); and Cercaria notocotylidae sp. 1, a parasite of $H$. australis and H. conexa (Etchegoin 1997). Only the last two forms have the primary excretory ducts as described above. Cercaria littoridinae differs from the present material in having a smaller cercarial body $(250 \times 110$ $v s 347-483 \times 137-213)$ and a smaller oral sucker $(28 \times 15$ vs $33-63 \times 27-47$ ), while Cercaria notocotylidae sp. 1 differs in having a shorter cercarial body (290-330 vs 347-483) and a smaller metacercarial cyst (55 vs 153-190). Notocotylids encyst predominantly on molluscan shells or on vegetation and mature in birds and mammals (Barton and Blair 2005). The notocotylid stages described here may belong to a recorded species whose life cycle has not yet been elucidated, or to an unrecorded species. 

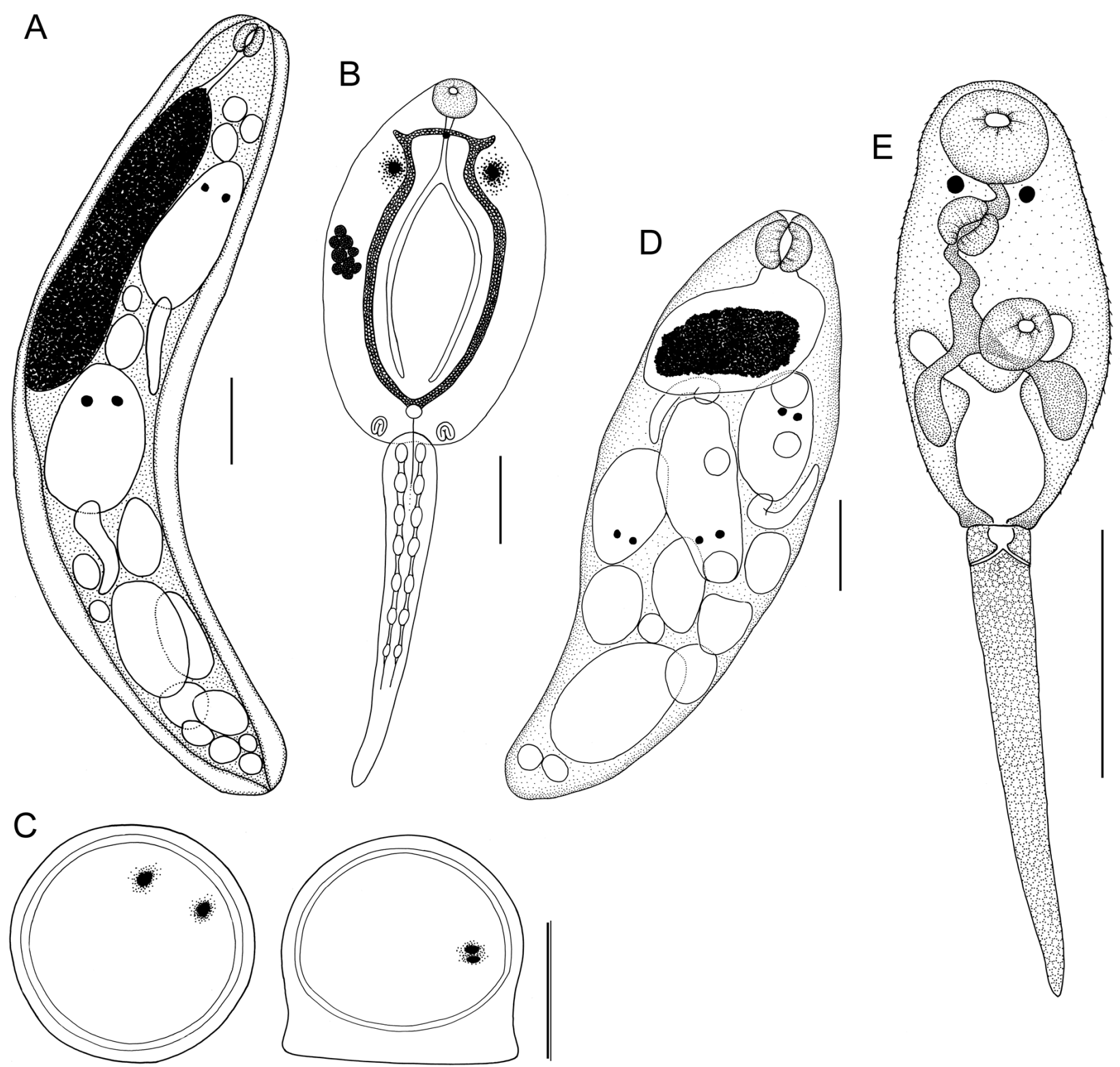

Fig. 3. Line drawings of the larval trematodes. A-C: Notocotylidae gen. sp. (A: redia, B: cercaria, cystogenous gland cells illustrated in detail in the left part of body, C: metacercaria); D-E: Haploporidae gen. sp. (D: redia, E: cercaria, cystogenous gland cells and penetration-gland cells not shown). Scale bars: A-E, $100 \mu \mathrm{m}$

\section{Haploporidae Nicoll, 1914}

Haploporidae gen. sp.

Voucher material: MPHC 6552.

Prevalence: $0.3 \%$.

\section{Redia (Fig. 3D)}

Found in digestive gland and gonad of $H$. australis. Body saclike, without appendages, 417-627 (523 $\pm 70, \mathrm{n}=10)$ long and $90-210(161 \pm 38, \mathrm{n}=10)$ wide, filled with germinal balls and developing cercariae. Pharynx 43-57 $(50 \pm 5, \mathrm{n}=10)$ long and 33-47 $(39 \pm 4, \mathrm{n}=10)$ wide; caecum dark, located in first third of body.

\section{Cercaria (Figs 2B, 3E)}

Biocellate, distomate cercaria with simple, slender tail. Body oval, 364-579 (479 $\pm 66, \mathrm{n}=13)$ long and 133-186 $(160 \pm 18$, $\mathrm{n}=13$ ) wide. Tegument covered with minute spines. Tail attached to pronounced terminal socket, $363-543(467 \pm 64$, $\mathrm{n}=9)$ long and 36-57 (44 $\pm 8, \mathrm{n}=11)$, wide near base, with dorsal groove almost reaching posterior extremity (only visible in SEM micrographs, Fig. 2B). Oral sucker subterminal, 53-100 $(86 \pm 17, \mathrm{n}=14)$ long and 67-114 $(95 \pm 14, \mathrm{n}=14)$ wide. Ventral sucker protruded, slightly postequatorial, 64-93 $(76 \pm 9, \mathrm{n}=12)$ long and $57-107(81 \pm 13, \mathrm{n}=12)$ wide. Eyespots located between oral sucker and pharynx. Prepharynx 
long; pharynx 50-57 (54 $\pm 3, \mathrm{n}=8)$ long and 33-50 (44 \pm 6 , $\mathrm{n}=8$ ) wide; oesophagus long, bifurcation anterior to ventral sucker; caeca extending close to posterior extremity of body, first half of caeca narrow, second half wide. Excretory vesicle Y-shaped, continues in small chamber that divides into 2 short ducts opening laterally in first quarter of tail. Flame-cell pattern and genital primordium not observed. Cercariae mature outside rediae, inside snail. After emerging, cercariae lose tails and encyst free in water column, probably becoming entangled in algal filaments.

Metacercaria (Fig. 2C)

Cyst oval, 160-233 $(200 \pm 26, \mathrm{n}=11) \times 130-230(179 \pm 35$, $\mathrm{n}=11)$. Wall bi-layered; inner layer hard, 3-19 $(8 \pm 5, \mathrm{n}=9)$ thick; outer layer thin, consists of 2 caps attached to inner cyst wall on both polar sides of cyst, each with 12-14 lateral filaments (only visible in SEM micrograph, Fig. 2C); filaments not attached to inner cyst wall and joined to each other at the ends.

\section{Remarks}

Characters such as the presence of eyespots, a stenostomate excretory system, oral and ventral suckers, a long tail in the cercaria, the lack of collar and stylet (gymnocephalous cer- caria), and the metacercaria encysting in aquatic environment place this trematode in the family Haploporidae (Overstreet and Curran 2005). Within this family, only three species have metacercariae with lateral extensions on the cyst wall: Saccocoelioides martini Madhavi, 1979 from Stenothyra blanfordiana Nevill, 1880 in India (Shameem and Madhavi 1991); Saccocoelioides pearsoni Martin, 1973 from Posticobia brazieri (Smith, 1882) in Australia (Martin 1973); and Culuwiya tilapiae Nasir et Gómez, 1976 from Pyrgophorus cf. spiralis (Guppy, 1864) in Venezuela (Díaz et al. 2009). The larval stage described here differs from all three species in the shape of the excretory vesicle. Many haploporid cercariae have been described parasitizing Heleobia spp.: Saccocoelioides octavus Szidat, 1970 in H. parchappii (Szidat 1970), Saccocoelioides sp. in Heleobia piscium (d'Orbigny, 1835) (Ostrowski de Núñez 1975), Saccocoelioides carolae Lunaschi, 1984 in H. parchappii (Martorelli 1986b), cercaria Haploporidae sp. 1 and cercaria Haploporidae sp. 2 in $H$. australis and H. conexa (Etchegoin 1997), Cercaria heleobicola III in H. australis and H. conexa (Martorelli 1989, Etchegoin 1997), and Dicrogaster fastigata Thatcher et Sparks, 1958 in H. conexa (Lado 2011). None of these haploporids, however, have a metacercaria with lateral extensions on the cyst wall. Haploporid cercariae encyst freely in the water column or in association with algae, and mature in marine and freshwater fish (Overstreet and Curran 2005). According to Shameem and Madhavi (1991),

Table II. Cercaria and redia of Psilochasmus oxyurus in the present study, in Szidat (1957), and in Etchegoin (1997). H: host; L: locality. Measurements in micrometers

\begin{tabular}{|c|c|c|c|}
\hline & $\begin{array}{c}\text { Present study } \\
\text { H: Heleobia australis } \\
\text { L: Bahía Blanca estuary }\end{array}$ & $\begin{array}{c}\text { Szidat, } 1957 \\
\text { H: Heleobia parchappii } \\
\text { L: Chascomús lagoon }\end{array}$ & $\begin{array}{c}\text { Etchegoin, } 1997 \\
\text { H: Heleobia conexa } \\
\text { L: Mar Chiquita coastal lagoon }\end{array}$ \\
\hline Body length & $382(350-423)$ & 580 & $1,150(1,050-1,220)$ \\
\hline Body width & $132(107-150)$ & 220 & $480(440-540)$ \\
\hline Oral sucker length & $59(57-60)$ & 70 (diameter) & $145(140-150)$ \\
\hline Pharynx length & $34(30-37)$ & 50 (diameter) & $62(60-68)$ \\
\hline Pharynx width & $27(23-30)$ & - & $47(45-53)$ \\
\hline Oesophagus length & $83(73-97)$ & - & - \\
\hline Oesophagus width & $32(27-40)$ & - & - \\
\hline Intestinal caeca length & $188(157-207)$ & - & - \\
\hline Tail length & $336(307-357)$ & - & $750(690-830)$ \\
\hline Tail width & $32(27-37)$ & - & $120(90-150)$ \\
\hline \multicolumn{4}{|l|}{ Redia } \\
\hline Body length & 1,538 & 950 & $1,890(1,540-2,210)$ \\
\hline Body width & 308 & 100 & $360(320-410)$ \\
\hline Pharynx length & 69 & 30 (diameter) & $34(30-38)$ \\
\hline Pharynx width & 92 & - & $42(38-45)$ \\
\hline
\end{tabular}


the long filaments of the metacercarial cyst of $S$. pearsoni and S. martini probably help them to become entangled in the algal filaments, the favorite food of mullets, thus aiding transmission. Such an entanglement could occur in the example of the metacercarial cyst described above. The larval trematode characterised here may be some undescribed haploporid species that parasitized mullets or other fish.

\section{Psilostomidae Looss, 1900}

\section{Psilochasmus oxyurus (Creplin, 1825)}

Prevalence: $0.1 \%$ (snail as first intermediate host); $0.2 \%$ (snails as second intermediate host).

\section{Remarks}

The morphology of the redia, cercaria, and metacercaria is consistent with those of Psilochasmus oxyurus. The most representative characteristics of the cercaria of this species are its having a body with numerous cystogenous gland cells and papillae with short setae, a tail with a dorsoventral fin fold covering the entire dorsal extension and the posterior third of ventral extension of tail, a wide oesophagus and caeca, an intestinal bifurcation anterior to ventral sucker, a large and protruded ventral sucker, a small excretory vesicle, and dark primary excretory ducts (Szidat 1957). The metacercariae of $P$. oxyurus is encysted in a large and round cyst with hard wall and the body has a large and protruded ventral sucker (Szidat 1957). The larval stages of Psilochasmus oxyurus were first described from $H$. parchappii by Szidat (1957). Etchegoin (1997) and Ostrowski de Núñez (2007) found $P$. oxyurus in $H$. conexa in the Mar Chiquita coastal lagoon and in a pond in the Zoological Garden in Buenos Aires City (Argentina), respectively; the latter author did not provide a description. The cercaria found in this study, however, was smaller (Table II) than the ones described by Szidat (1957) and Etchegoin (1997). This intraspecific variability could be related to the ability of the parasite to infect different species of Heleobia. Another possible explanation of the variability observed in the measurements could be the existence of different species of Psilochasmus infecting different species of Heleobia. Further molecular-genetic and morphological studies are required to test these hypotheses. Szidat (1957) investigated the life cycle of $P$. oxyurus and found the metacercaria to be encysted in the visceral sac of $H$. parchappii in Chascomús lagoon. In the present study, we found the metacercaria encysted between the mantle and the shell of $H$. australis. Psilochasmus oxyurus is a cosmopolitan and widespread parasite species-or possibly a species complex-of birds (Fernandes et al. 2007). Psilochasmus oxyurus was first described as Distoma oxyurum Creplin, 1825 in Anas spp. from the Baltic Sea (Creplin 1825), and many other reports have followed since then (Fernandes et al. 2007). In the Bahía Blanca estuary, other birds could be parasitized with $P$. oxyurus apart from the one reported, the white-backed stilt
Himantopus melanurus Vieillot, 1817 (Alda et al. 2011b). This report constitutes the first record of $P$. oxyurus parasitizing $H$. australis.

\section{Echinostomatidae Looss, 1899 \\ Himasthla sp.}

Voucher material: MPHC 6551.

Prevalence: $0.1 \%$.

Redia (Figs 4A-B)

Body elongate, 792-2,114 (1,543 $\pm 48, \mathrm{n}=10)$ long and 185-300 (247 $\pm 36, \mathrm{n}=10)$ wide, contains up to 7 developing cercariae. Pharynx 47-69 (60 $\pm 8, \mathrm{n}=8)$ long and 31-53 (44 $\pm 8, \mathrm{n}=8$ ) wide; intestine short, dark. Cercarial development is completed outside redia in host tissues. Immature rediae with posterior appendage and collar posterior to pharynx.

\section{Cercaria (Figs 2D, 4C-D)}

Body elongate, 407-743 (511 $\pm 110, \mathrm{n}=10)$ long and 140 $207(177 \pm 21, \mathrm{n}=10)$ wide at level of ventral sucker. Tegument with small spines located in holes only visible in SEM (Fig. 2D). Numerous cystogenous gland cells containing rodlike inclusions. Head collar with 26-29 (28) spines: 2 angle spines, 4-5 lateral spines and 14-15 dorsal spines in single dorsally uninterrupted row, 14-19 $(16 \pm 2, \mathrm{n}=9)$ long and 3-5 ( $4 \pm 1, \mathrm{n}=9)$ wide (Fig. 4D). Tail inserted terminally, almost as long as body when extended, 293-477 (359 \pm 58 , $\mathrm{n}=10)$ long and $23-43(36 \pm 6, \mathrm{n}=10)$ wide at anterior level. No fin folds or setae present. Oral sucker subterminal, $43-57(49 \pm 5, \mathrm{n}=11)$ long and 47-63 (56 $\pm 5, \mathrm{n}=10)$ wide Ventral sucker round, protruded, postequatorial, 87-103 (95 $\pm 6, \mathrm{n}=10)$ long and 80-110 (96 $\pm 10, \mathrm{n}=10)$ wide. Prepharynx, 3-33 (11 $\pm 9, \mathrm{n}=9)$ long; pharynx, 30-63 (43 $\pm 10 \mathrm{n}=10)$ long and 13-20 (16 $\pm 3, \mathrm{n}=10)$ wide; oesophagus, 127-267 (161 $\pm 43, \mathrm{n}=9)$ long, bifurcates anterior to ventral sucker; caeca extending to posterior end of body, 3-13 ( $8 \pm 3, n=9)$ wide. Five pairs of penetration gland cells lateral to anterior half of oesophagus arranged in a pair of rows; ducts run in 2 groups and open via 2 groups of 5 outlets on dorsal lip of oral sucker. Flame cells abundant (total number not determined): 7 flame cells in prepharyngeal area and 3 lateral to pharynx more distinct. Excretory vesicle small and transverse-oval; primary excretory ducts dilated, each with 17-20 pairs of single and double bilateral branches between mid-level of ventral sucker and collar; primary ducts and branches filled with large spherical refractive granules from excretory vesicle to level of pharynx; primary ducts reach to level of oral sucker, forming anterior loop, secondary ducts narrow, give rise to ciliated collecting ducts and flame-cells posterior to ventral sucker. Caudal excretory duct divided into 2 short ducts opening laterally at $1 / 4$ of tail length. Cercariae very motile, beating tail from side to side with body contracted. 

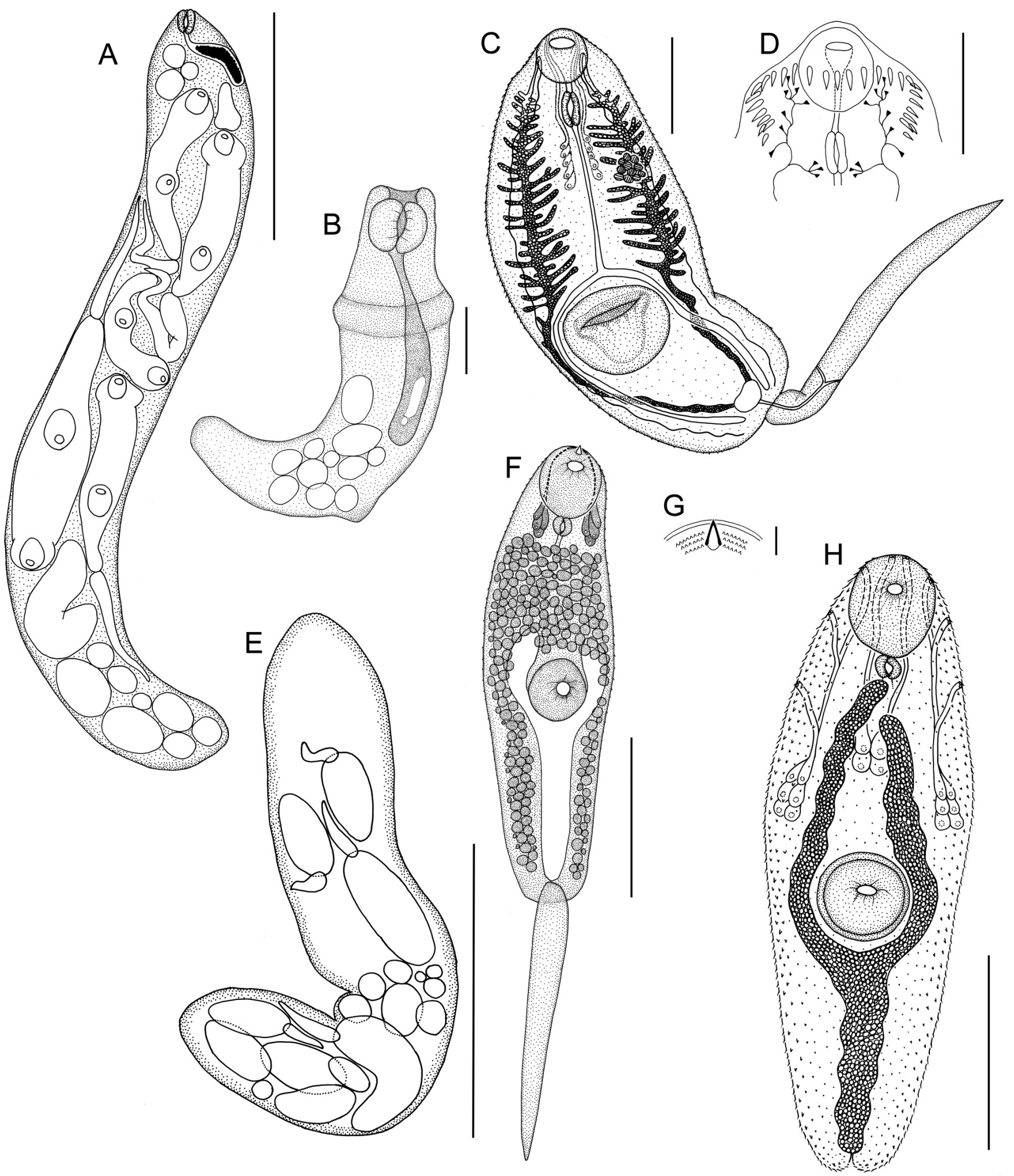

Fig. 4. Line drawings of the larval trematodes. A-D: Himasthla sp. (A: mature redia, B: immature redia, C: cercaria, D: anterior part of cercaria in detail); E-G: Renicola sp. (E: daughter sporocyst, F: cercaria, G: anterior part of cercaria in detail); H: Renicolidae gen. sp. Scale bars: A-B, D-E, H: $100 \mu \mathrm{m} ; \mathrm{C}, \mathrm{G}, 500 \mu \mathrm{m}$; F: $10 \mu \mathrm{m}$ 


\section{Remarks}

The presence of a head collar with spines places this larval stage in the family Echinostomatidae (Schell 1970). Species of the genera Acanthoparyphium Dietz, 1909 and Himasthla Dietz, 1909 (Subfamily Himasthlinae Odhner, 1910) possess cercariae with excretory ducts with lateral branches. All species of Acanthoparyphium, however, have 23 collar spines with no angle spines (Kostadinova 2005). Cercaria heleobicola $V$ reported as parasitizing $H$. conexa is the only cercaria with excretory ducts having lateral branches that has been described as a parasite of Heleobia spp. up to the present (Martorelli 1990, Etchegoin 1997). The cercaria described above differs from Cercaria heleobicola $V$ in having a tegument with spines, an excretory chamber in the tail, a smaller body (407$743 \times 140-207$ vs $883 \times 300)$, a smaller oral sucker $(43-57 \times$ $47-63$ vs 96$)$, a smaller ventral sucker $(87-103 \times 80-110$ vs $130)$, a narrower pharynx (13-20 vs 40 ), a narrower tail (2343 vs 85 ), and smaller collar spines $(14-19 \times 3-5$ vs $65 \times 20$ ). Molluscs and polychaetes have been reported as second intermediate hosts of the species within the genus Himasthla (Kostadinova 2005). Himasthla sp. parasitizing H. australis in the Bahía Blanca estuary may be Himasthla escamosa Diaz et Cremonte, 2004, a recently reported parasite of gulls in this estuary (La Sala et al. 2009) whose life cycle is still not elucidated.

\section{Stephanoprora uruguayensis Holcman-Spector et Olagüe, 1989}

Prevalence: $0.1 \%$.

\section{Remarks}

The morphologic features of the redia from the digestive gland and gonad of $H$. australis and the cercaria examined by us are consistent with the characteristics of the larval stages of $S$. uruguayensis as described by Ostrowski de Núñez (2007). The cercaria of this species has a head collar poorly developed without spines, a tail with brownish pigment on posterior fourth, longitudinal and circular muscle fibers, flattened spines on oral and ventral sucker (Figs 2EF), a prepharyngeal body present, cystogenous cells with bar-shaped contents between pharynx and end of body, primary excretory ducts narrow without refractile granules, 16 flame cells, and a caudal excretory duct extending into the tail and bifurcating at the base of the tail into unequal branches ending blindly (Ostrowski de Núñez 2007). The cercariae of this species seem to exhibit a wide tolerance to salinity since the trematode has been recorded in the freshwater snail, $H$. parchappii, and for the first time in an estuarine snail, $H$. australis in our study. Ostrowski de Núñez (2007) elucidated the life cycle of $S$. uruguayensis using the fish Cnesterodon decemmaculatus (Jenyns, 1842) and chicks as second-intermediate and definitive host, respectively.

\section{Microphallidae Ward, 1901}

\section{Maritrema orensense Cremonte et Martorelli, 1998}

Combined prevalence of $M$. orensense, $M$. bonaerense, and L. cruzi: $1.7 \%$

Remarks

The sporocyst and cercaria of $M$. orensense from the digestive gland and gonad of $H$. australis were described by Alda et al. (2013). The cercaria of M. orensense has a small body without ventral sucker, a stylet with a pointed anterior margin, large and undulating penetration glands with no discernible nuclei and posterior extent just over 3/4 way from anterior to posterior body margin, and a V-shaped excretory vesicle (Alda et al. 2013). The life cycle of this species includes the grapsid crabs Neohelice granulata (Dana, 1851) and Cyrtograpsus angulatus Dana, 1851 and the gulls Larus atlanticus Olrog, 1958 and Larus dominicanus Lichtenstein, 1823 as second-intermediate and definitive hosts, respectively (see Alda et al. 2013).

\section{Maritrema bonaerense Etchegoin et Martorelli, 1997}

Combined prevalence of $M$. orensense, $M$. bonaerense, and L. cruzi: $1.7 \%$

\section{Remarks}

The sporocyst and cercaria of $M$. bonaerense from the digestive gland and gonad of $H$. australis were described by Etchegoin and Martorelli (1997) and redescribed by Alda et al. (2013). The cercaria of $M$. bonaerense has a small body without ventral sucker; a stylet with pointed anterior margin; small and rounded penetration glands with visible nuclei, posterior extent just over $2 / 3$ way from anterior to posterior body margin, and ventral pairs staining lighter with neutral red than dorsal pairs; and a V-shaped excretory vesicle (Etchegoin and Martorelli 1997, Alda et al. 2013). The life cycle of this species includes grapsid crabs $N$. granulata and $C$. angulatus and the gulls L. atlanticus, L. dominicanus, and Larus maculipennis Lichtenstein, 1823 as second-intermediate and definitive host, respectively (see Alda et al. 2013).

\section{Levinseniella cruzi Travassos, 1920}

Combined prevalence of $M$. orensense, $M$. bonaerense, and $L$. cruzi: $1.7 \%$

\section{Remarks}

The sporocyst and cercaria of $L$. cruzi from the digestive gland and gonad of $H$. australis were described in $H$. conexa and H. parchappii (Martorelli 1988, Etchegoin 1997). The cercaria of $L$. cruzi has a small body without ventral sucker; a stylet with pointed anterior margin; small and constricted penetration glands with visible nuclei, posterior extent just over $2 / 3$ 
way from anterior to posterior body margin, and ventral pairs staining lighter with neutral red than dorsal pairs; and a V-shaped excretory vesicle (Martorelli 1988). The present record is the first of the species from $H$. australis. The shrimp Palaemonetes argentinus Nobili, 1901 and the crabs N. granulata and $C$. angulatus have been reported as second-intermediate (Martorelli 1988, Alda et al. 2011a) and Rollandia rolland chilensis (Lesson, 1828), Himantopus melanurus, Vanellus chilensis (Molina, 1782), and L. atlanticus as definitive (Martorelli 1988, Martorelli and Ivanov 1996) hosts.

\section{Microphallus simillimus (Travassos, 1920)}

Prevalence: $24.2 \%$.

Sporocyst

Found in digestive gland and gonad of $H$. australis. Body saclike, 158-277 (211 $\pm 39, \mathrm{n}=6)$ long and 53-107 (72 \pm 19 , $\mathrm{n}=6$ ) wide with thin wall very difficult to differentiate and 2-5 metacercariae inside.

\section{Metacercaria (Figs 5A-C)}

Cyst rounded to oval 58-85 $(75 \pm 8, \mathrm{n}=10) \times 78-119(98 \pm$ $13, \mathrm{n}=10)$, wall bi-layered. Inner layer $2-5(3 \pm 1, \mathrm{n}=10)$ thick, outer layer thin and easy to remove. Body pyriform with extremities ventrally curved (Fig. 5A), 159-192 (178 \pm 11 , $\mathrm{n}=10)$ long and 103-139 $(116 \pm 12, \mathrm{n}=10)$ wide at testicular level. Entire body covered with numerous spines being ventrally $\sim 1.5 \mu \mathrm{m}$ long, situated close to each other, and scalelike with 5-6 indentations projecting posteriorly (Fig. 5B) while dorsally being $\sim 0.7 \mu \mathrm{m}$ long, situated one spine width from each other, and scale-like with 3-5 indentations projecting posteriorly (Fig. 5C). Oral sucker subterminal, round, 22 $34(30 \pm 4, n=9)$ long and 24-47 $(33 \pm 7, n=9)$ wide. Ventral sucker round, postequatorial, 22-34 (30 $\pm 4, \mathrm{n}=9)$ long and 25-34 $(31 \pm 3, \mathrm{n}=9)$ wide. Prepharynx not observed; pharynx $12-17(14 \pm 2, \mathrm{n}=8)$ long and $12-17(13 \pm 2, \mathrm{n}=8)$ wide; oesophagus, 29-46 (38 $\pm 5, \mathrm{n}=8)$ long; caeca almost reaching posterior end of ovary, 53-90 $(67 \pm 10, \mathrm{n}=9)$ long and $5-12(8 \pm 2, n=9)$ wide. Testicules rounded to oval, lateral and posterior to caeca; right testicule 22-36 (27 \pm 6 , $\mathrm{n}=5)$ long and $17-31(23 \pm 5, \mathrm{n}=5)$ wide; left testicule 20 $42(27 \pm 8, \mathrm{n}=6)$ long and $15-36(26 \pm 7, \mathrm{n}=6)$ wide. Ovary right of ventral sucker, 19-39 $(30 \pm 8, \mathrm{n}=7)$ long and 25-41 $(35 \pm 5, n=7)$ wide. Seminal vesicle immediately posterior to intestinal bifurcation. Male papilla round, left of ventral sucker (Fig. 5A). Vitellarium translucent to brown, arranged in 2 large masses located at posterior part of body, joined posteriorly to ventral sucker, covering interior half of testes, 20-47 (33 \pm 11 , $\mathrm{n}=6)$ long and 22-51 (35 $\pm 12, \mathrm{n}=6)$ wide. Eggs 15-31 $(22 \pm 5, \mathrm{n}=8)$ long and 8-14 $(11 \pm 2, \mathrm{n}=8)$ wide developed in encysted metacercariae and those excysted after incubation in saline solution facilitating excystment.

\section{Remarks}

The sporocyst and metacercaria of $M$. simillimus from $H$. australis has been previously reported as a parasite of $H$. conexa by Martorelli (1991) and of H. australis by Alda et al. (2010). The most distinctive features of $M$. simillimus are its having a metacercariae that encyst inside the snail and with a round male papilla located left to ventral sucker, vitellarium arranged in 2 large masses located at posterior part of body, and large eggs compared to other species of Microphallus (Martorelli 1991). Microphallus simillimus described by Martorelli (1991) differs from the present material in having a cercaria (not observed in this study), a larger sporocyst (500-1,100 × 125-350 vs $158-277 \times 53-107)$ with more metacercariae inside $(10$ 40 vs 2-5), and a metacercaria with a short prepharynx (not
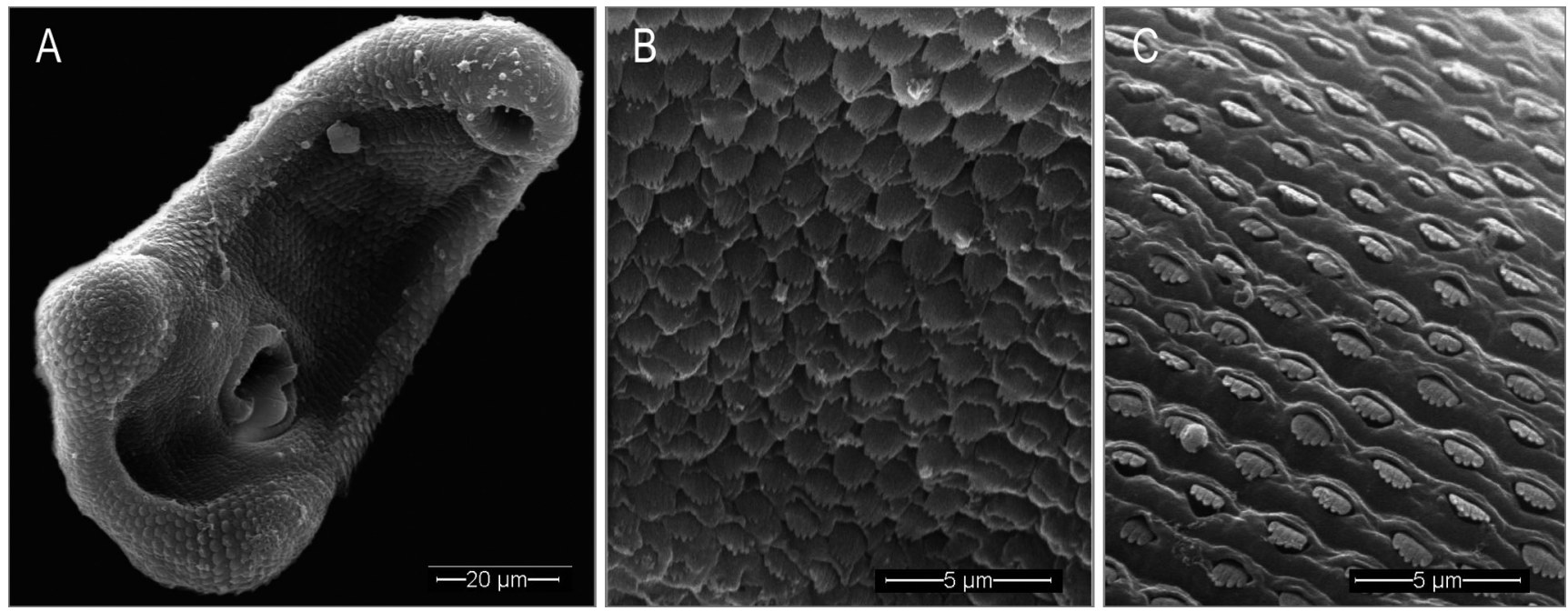

Fig. 5. Larval trematodes under scanning electron microscopy. A-C: Microphallus simillimus (A: metacercaria excysted, B: ventral tegument of metacercaria, C: dorsal tegument of metacercaria). 
observed in this study). Microphallus simillimus has an abbreviated life cycle involving two hosts (Martorelli 1991). Sporocysts, cercariae, and metacercariae encysted within the sporocysts in the gonad and digestive gland of the snail intermediate host. The adult stage of $M$. simillimus has been found in the white-backed stilt Himantopus melanurus (Martorelli 1991).

\section{Renicolidae Dollfus, 1939 \\ Renicola sp.}

Voucher material: MPHC 6550.

Prevalence: $1.3 \%$.

Sporocyst (Fig. 4E)

Daughter sporocyst elongate, $623-1,485(1,109 \pm 317, \mathrm{n}=11)$ long and 135-346 $(223 \pm 72, \mathrm{n}=11)$ wide, with blunt anterior and posterior extremities, containing up to 8 cercariae. Sporocysts infect digestive gland of $H$. australis.

\section{Cercaria (Figs 4F-G)}

Body elongate, $220-447(352 \pm 52, \mathrm{n}=20)$ long and $110-180$ $(145 \pm 19, \mathrm{n}=20)$ wide, covered with tiny spines. Abundant acicular spines arranged in 3 rows on anterior border (Fig. $4 G)$. Stylet small, triangular, lateral sides deeply sclerotised, concave base not sclerotised, $7-11(10 \pm 2, \mathrm{n}=15)$ long and 5-7 $(6 \pm 1, \mathrm{n}=15)$ wide (Fig. 4G). Tail simple, 147-267 (218 $\pm 35, \mathrm{n}=17)$ long and $27-53(38 \pm 7, \mathrm{n}=16)$ wide at base. Oral sucker subterminal, spherical, $37-70(54 \pm 9, \mathrm{n}=20)$ long and 40-60 $(53 \pm 6, n=20)$ wide. Ventral sucker spherical, protuberant, equatorial, 37-60 $(50 \pm 6, \mathrm{n}=18)$ long and 40-67 $(55 \pm 7, \mathrm{n}=18)$ wide. Prepharynx not observed; pharynx spherical, $13-27(19 \pm 3, \mathrm{n}=17)$ long and $12-23(19 \pm 3$, $\mathrm{n}=17$ ) wide; oesophagus and intestine not observed (masked by abundant cystogenous gland cells). Four pairs of penetration gland cells located laterally to pharynx, ducts open laterally to stylet. Genital primordium not observed. Excretory vesicle Y-shaped with lateral branches that surpass ventral sucker, excretory pore at tail tip, flame-cell formula not determined (flame cells obscured by cystogenous gland cells). Cercaria swims bending posterior extremity downward and vibrating tail laterally. On bottom, cercaria moves by alternately extending anterior extremity and stretching and contracting tail.

\section{Remarks}

The features of this cercaria-distome with stylet and tail shorter than body, sinuous tegument, and Y-shaped excretory vesicle-are consistent with the characteristics of the $3^{\circ}$ group of cercariae Renicolidae reported by Martin (1971): cercariae with short tails and with or without stylet. This morphology is similar to those of the cercariae of the genus Renicola Cohn, 1904 (Renicolidae) (Stunkard 1964b). According to Martorelli et al. (2008), ten cercariae with stylet and short tail have been described. Cercariae of two trematodes with stylets similar to those described here and short tails have been reported as parasites of $H$. conexa: Xiphidiocercaria sp. 1 and Xiphidiocercaria sp. 2 (Etchegoin 1997, Etchegoin and Martorelli 1998). The cercaria described here differs from Xiphidiocercaria sp. 1 in having an excretory vesicle with lateral branches that surpass the ventral sucker, a larger body $(220-447 \times 110-180 \mathrm{vs}$ $80-98 \times 30-41)$, a larger tail $(147-267 \times 27-53$ vs $58-70 \times 8$ 11), a larger oral sucker $(37-70 \times 40-60$ vs $14-19 \times 12-17)$, a larger ventral sucker $(37-60 \times 40-67$ vs $20-25 \times 18-23)$, and a larger pharynx $(13-27 \times 12-23$ vs $7-8 \times 6-7)$. The cercaria described above, though, is similar to Xiphidiocercaria sp. 2, the only difference being the wider stylet (5-7 vs 3-4). Renicolids are parasites of birds that feed on bivalves or fish (Gibson 2008). No adult trematodes of this family have been recorded from the southwestern Atlantic coasts to date. The cercaria described here may belong to an as-yet-undescribed species of Renicola.

\section{Renicolidae gen. sp.}

Voucher material: MPHC 6549

Prevalence: $2.3 \%$

Metacercaria (Fig. 4H)

Cyst 169-269 $(202 \pm 33, \mathrm{n}=9)$ in diameter, wall bi-layered. Inner layer hard, 3-8 $(6 \pm 2, \mathrm{n}=9)$ thick, outer layer 8-19 $(14 \pm 4, n=9)$ thick. Body of excysted metacercaria elongate, 251-603 (400 $\pm 107, \mathrm{n}=9)$ long and 78-167 (114 \pm 25 , $\mathrm{n}=9$ ) wide at level of ventral sucker, densely covered with spines. Oral sucker subterminal, $24-80(60 \pm 15, \mathrm{n}=10)$ long and $31-73(54 \pm 12, n=10)$ wide. Ventral sucker protuberant, 44-87 $(61 \pm 15, n=9)$ long and 36-81 $(60 \pm 5, n=9)$ wide, with small spines on inner lip. Prepharynx not observed; pharynx 15-28 (22 $\pm 5, \mathrm{n}=5)$ long, $15-25(20 \pm 4, \mathrm{n}=5)$ wide; oesophagus and intestinal caeca not observed (masked by abundant cystogenous gland cells). Two pairs of gland cells located posterior to pharynx and between lateral branches of excretory vesicle, ducts run in 2 groups and open anteriorly to oral sucker; 6 pairs of lateral gland cells, ducts run laterally and open in 3 groups of 2 posterior to pharynx, anterior to pharynx, and anterior to mouth. Excretory vesicle Y-shaped, with lateral branches and numerous granules excretory pore terminal; flame-cell formula $2[(2+2)+(2+2)]=16$ (not illustrated). Metacercariae encysted in head of $H$. australis.

\section{Remarks}

This metacercaria resembles the metacercariae of trematodes of the family Renicolidae found in bivalves and fish (Gibson 2008). We tentatively place this metacercaria in that family and, to the best of our knowledge, this assignment would mark the first example of a renicolid metacercaria parasitizing a snail. We suspect that this metacercaria may belong to the 
same species of Renicola described above, but experimental infections or molecular studies are needed to confirm this suggestion and to elucidate the life cycle of this trematode.

\section{Discussion}

In a two-year sampling, we found 15 different trematodes that infect $H$. australis in the Bahía Blanca estuary (Argentina). The intertidal mud snail $H$. australis plays a key role in the life cycles of trematodes that infect fish, birds, and probably mammals in the Bahía Blanca estuary (Table I)-very likely also in other south-Atlantic estuaries as well since the snail is a major biotic component. In the Bahía Blanca estuary, $H$. australis would be the most relevant first intermediate host among the gastropods, but also other species of snails could also be playing this role for some of the larval-trematodes species described in this study. Elías et al. (2004) reported-in addition to H. australis but in much lower abundance - other species of gastropods inhabiting the estuary: Buccinanops globulosus (Kiener, 1834) (Nassariidae), Anachis peassleri Strebel, 1905 (Columbellidae), and Olivella tehuelcha (Duclos, 1835) (Olivellidae).

Of the 15 trematodes found in $H$. australis in the Bahía Blanca estuary, four species $-A$. (P.) longa, $M$. bonaerense, $M$. orensense, and $M$. simillimus - have been previously found in this host (Etchegoin 1997, Etchegoin and Martorelli 1997, Simões et al. 2010, Alda et al. 2010, 2013), three speciesS. uruguayensis, L. cruzi, and P. oxyurus - have been reported in other species of Heleobia (Szidat 1957, Martorelli 1988, Etchegoin 1997, Ostrowski de Núñez 2007), and eight trematode species still remain unidentified until experimental infections or molecular-genetic studies have been done. Finding such a high species richness of trematodes is not uncommon among Heleobia spp. In the Mar Chiquita coastal lagoon, some $260 \mathrm{~km}$ northeast of the Bahía Blanca estuary, Merlo and Etchegoin (2010) found 22 species of larval trematodes parasitizing $H$. conexa, while Etchegoin (1997) found 13 species of larval trematodes parasitizing $H$. australis. Cryptogonimidae gen. sp., $P$. oxyurus, and the microphallids $M$. bonaerense, L. cruzi, and M. simillimus were present in both environments.

Heterophyids are the richest taxon among the trematodes that infect Heleobia conexa from the Mar Chiquita coastal lagoon and Heleobia parchappii from freshwater environments of the Buenos Aires Province, Argentina ( $c f$. references in Ostrowski de Núñez 2001, Merlo and Etchegoin 2010). In Heleobia australis from Bahía Blanca estuary, however, we found only one species of heterophyid: $A$. (P.) longa. Even though heterophyid species inhabit marine and freshwater environments, in Argentina they would be more frequent in freshwater habitats $(c f$. references in Ostrowski de Núñez 2001). Thus we think that the rarity of heterophyids observed in Bahía Blanca estuary could be a result of the marine condition of the estuary (Freije and Marcovecchio 2004). In the Bahía Blanca estuary, microphallids are the richest and the most prevalent taxon. This finding could be explained by the high abundance of grapsid crabs-the second-intermediate hosts of the microphallid species (Alda et al. 2011a), except for $M$. simillimus-along with the high diversity of gulls (Petracci and Delhey 2005). Microphallids also prevail in the intertidal gastropods from the Patagonian coast in Argentina (Gilardoni et al. 2011) and in the rissooids of the European coast (Deblock 1980, Kube et al. 2002, Skirnisoon et al. 2004, Thieltges et al. 2009).

In spite of a high overall prevalence (28\%), the individual prevalence of trematodes that infect $H$. australis in the Bahía Blanca estuary was low $(<3 \%)$, as in H. australis from the Mar Chiquita coastal lagoon (Etchegoin 1997), except for the high prevalence of M. simillimus (at $>20 \%$ ). This elevated prevalence could be the result of the high abundance of the definitive host of this parasite, $H$. melanurus, and perhaps other birds too in the Bahía Blanca estuary (Alda et al. 2010). This kind of larval trematode assemblage- $i$. e. with most trematode species showing low prevalence except for one or two species with a high abundance-is in fact, common in larval trematode assemblages of the rissooids from Europe, Oceania, and America (Deblock 1980, Jokela and Lively 1995, Kube et al. 2002, Skirnisoon et al. 2004, Thieltges et al. 2009, Merlo and Etchegoin 2010).

In H. conexa from the Mar Chiquita coastal lagoon, the individual prevalences were also low, except for those of a notocotylid, a heterophyid, and two microphallids (Microphallus szidati and M. simillimus); but none of them present at higher levels than 9\% (Merlo and Etchegoin 2010). Microphallus szidati was not found in the Bahía Blanca estuary-where, as mentioned previously, marine conditions prevail (Freije and Marcovecchio 2004)-probably because this species is, rather, a brackish and freshwater trematode, having been described as a parasite of $H$. conexa in the Mar Chiquita coastal lagoon and of $H$. parchappii in a freshwater environment from Buenos Aires province. Microphallus simillimus was more prevalent in Bahía Blanca estuary (24\%) than in the Mar Chiquita coastal lagoon (1-8.6\%). As mentioned earlier, this elevated prevalence could be explained by the higher abundance of the definitive host of this parasite in the Bahía Blanca estuary; but also by the lower prevalence of dominant trematode species in that estuary than in the Mar Chiquita coastal lagoon. Dominant species-generally trematodes with rediae as intramoluscan stages-compete with and replace subordinate species-generally trematodes with sporocysts as intramollucan stages (Lafferty et al. 1994). Dominant species, such as echinostomatids, notocotilids, and heterophyids, feed on subordinate species, such as microphallids, causing a decrease in the prevalence of the latter. These last authors reported that competition among trematodes displaces $16 \%$ of those infecting Cerithidea californica (Haldeman, 1840). In the Bahía Blanca estuary the prevalence of dominant species-although a dominance hierarchy has not yet been constructed - would be low, thus allowing a higher prevalence of subordinate species such as $M$. simillimus. 
Acknowledgements. We would like to thank the anonymous reviewers for their critical evaluation of the manuscript and their constructive suggestions. We thank Charly from Club de Pesca y Náutica Gral. Daniel Cerri for helping in the snail collection and Ernesto Alda and Camely Covas for providing accommodations during sampling. We also thank Néstor Cazzaniga for helping with zoological nomenclature, Luis Giambelluca for collaborating with the photographic shooting, Emilio Topa for the histological sections, and Mariela Theiller from Servicio de Microscopía Electrónica de Barrido y Microanálisis (CINDECA) for the scanning-electron-microscopy micrographs. We are also grateful to Dr. Donald F. Haggerty, a retired career investigator and native English speaker, for editing the final version of the manuscript. This work was partially funded by a research grant from the Agencia Nacional de Promoción Científica y Técnica (PICT 34412/05) and Consejo Nacional de Investigaciones Científicas (PID 0257) to SRM.

\section{References}

Alda P., Bonel N., Cazzaniga N., Martorelli S.R. 2010. Effects of parasitism and environment on shell size of the South American intertidal mud snail Heleobia australis (Gastropoda). Estuarine, Coastal and Shelf Science, 87, 305-310. DOI:10.1016/ j.ecss.2010.01.012.

Alda P., Bonel N., Martorelli S.R., Hechinger R.F. 2013. Maritrema orensense and Maritrema bonaerense (Digenea: Microphallidae): descriptions, life cycles, and comparative morphometric analyses. Journal of Parasitology, 99, 218-228. DOI: 10.1645/GE-3238.1

Alda P., La Sala L., Marcotegui P., Martorelli S.R. 2011a. Parasites and epibionts of grapsid crabs in Bahía Blanca estuary, Argentina. Crustaceana, 84, 559-571. DOI:10.1163/0011216 11 X557046

Alda P., Martorelli S., Sarria R. 2011b. Digenean parasites in the White-backed Stilt Himantopus melanurus (Recurvirostridae) from the Argentine coast. Comparative Parasitology, 78, $217-$ 219. DOI: 0.1654/4479.1.

Avendaño de Mac Intosh F., Ostrowski de Núñez M. 1998. Seasonal dynamics of Plehniella coelomica Szidat, 1951 (Trematoda, Sanguinicolidae) in two catfish, Pimelodus albicans and $P$. maculatus, from La Plata River, Argentina. Folia Parasitologica, 45, 253-255.

Barton D.P., Blair D. 2005. Family Notocotylidae Lühe, 1909. In: (Eds. A. Jones, R.A. Bray and D.I. Gibson) Keys to the Trematoda. Vol. 2. CABI Publishing and The Natural History Museum, Wallingford, 383-396.

Bullard S.A., Jensen K., Overstreet R.M. 2009. Historical account of the two family-group names in use for the single accepted family comprising the "fish blood flukes". Acta Parasitologica, 54, 78-84. DOI: 10.2478/s11686-009-0012-8.

Bush A.O., Lafferty K.D., Lotz J.M., Shostak A.W. 1997. Parasitology meets ecology on its own terms. Margolis et al. revisited. Journal of Parasitology, 83, 575-583.

Carnevia D., Perreta A., Venzal J.M., Castro O. 2004. Heleobia australis (Mollusca, Hydrobiidae) y Mugil platanus (Pisces, Mugilidae), primer y segundo hospedador intermediario de Ascocotyle (Phagicola) longa (Digenea, Heterophyidae) en Uruguay. Revista Brasileira de Parasitologia Veterinária, 13, 283.

Castro O., Carnevia D., Perretta A., Venzal J.M. 2006. Comunidad componente de tremátodos larvales de Heleobia australis (Mollusca, Cochliopidae) en la costa uruguaya del Río de la Plata. In: (Eds. R. Menafra, L. Rodríguez-Gallego, F. Scarabino, and D. Conde) Bases para la conservación y el manejo de la costa uruguaya. Vida Silvestre, Montevideo, 421-425.
Combes C. 1980. Atlas mondial des cercaires. Mémoires du Muséum national d'Histoire Naturelle. Nouvelle série, Série A, Zoologie, $115,1-235$.

Creplin FChH. 1825. Observationes de Entozois. I. Gryphiswaldiae: Sumtibus Mauritii Librarii, Greifswald, 86 pp.

Cribb T.H. 2005. Family Apocreadiidae Skrjabin 1942. In: (Eds. A Jones, R.A. Bray and D.I. Gibson) Keys to the Trematoda. Vol. 2. CABI Publishing and The Natural History Museum, Wallingford, 621-639.

Cribb T.H., Adlard R.D., Hayward A., Bott N.J., Ellis D., Evans D., Nowak B.F. 2011. The life cycle of Cardicola forsteri (Trematoda Aporocotylidae), a pathogen of ranched southern bluefin tuna. International Journal for Parasitology, 41, 861-870. DOI:10.1016/j.ijpara.2011.03.011.

Cribb T.H., Bray R.A., Littlewood D.T.J. 2001. The nature and evolution of the association among digeneans, molluscs and fishes. International Journal for Parasitology, 31, 997-1011.

De Francesco C.G., Isla F. 2004. Reproductive period and growth rate of the freshwater snail Heleobia parchappii (d'Orbigny, 1835) (Gastropoda: Rissooidea) in a shallow brackish habitat (Buenos Aires Province, Argentina). Malacologia, 45, 443 450.

De Francesco C.G., Isla F. 2003. Distribution and abundance of hydrobiid snails in mixed estuary and a coastal lagoon, Argentina. Estuaries, 26, 790-797.

Deblock S. 1980. Inventaire des Trématodes larvaires parasites de mollusques Hydrobia (Prosobranches) des côtes de France. Parassitologia, 22, 1-105.

Díaz M.T., Bashirullah A.K., Hernández L.E., Gómez E. 2009. Life cycle of Culuwiya tilapiae (Nasir y Gómez, 1976) (Trematoda: Haploporidae). Revista Cientifica, 19, 439-445.

Elías R., Iribarne O., Bremec C.S., Martínez D.E. 2004. Comunidades bentónicas de fondos blandos. In: (Eds. M.C. Piccolo and M.S. Hoffmeyer) Ecosistema del Estuario de Bahía Blanca. EDIUNS (UNS), Bahía Blanca, 179-190.

Etchegoin J.A. 1997. Sistemas parasitarios presentes en la albufera Mar Chiquita. Doctoral thesis. Facultad de Ciencias Exactas y Naturales, Universidad Nacional de Mar del Plata, Mar del Plata, Argentina.

Etchegoin J.A., Martorelli S.R. 1997. Description of a new species of Maritrema (Digenea: Microphallidae) from Mar Chiquita coastal lagoon (Buenos Aires, Argentina) with notes on its life cycle. Journal of Parasitology, 83, 709-713.

Etchegoin J.A., Martorelli S.R. 1998. Nuevas cercarias en Heleobia conexa (Mollusca: Hydrobiidae) de la albufera de Mar Chiquita. Neotropica, 44, 41-50.

Fernandes B.M.M., Menezes R.C., Tortelly R., Noronha D., Pinto R.M. 2007. First report of the digenetic trematode Psilochasmus oxyurus (Creplin) in the domestic goose, Anser anser (Linnaeus) in South America. Revista Brasileira de Zoologia, 24, 520-522. DOI: 10.1590/S0101-81752007000200037.

Flores V.R. 2004. Estructura comunitaria de digeneos larvales en $\mathrm{Chi}$ lina dombeiana y Heleobia hatcheri (Mollusca: Gasteropoda) de la región andino Patagónica. Doctoral thesis. Universidad Nacional del Comahue, Bariloche, Argentina.

Flores V.R., Brugni N. 2006. Catatropis hatcheri n. sp. (Digenea: Notocotylidae) from Heleobia hatcheri (Prosobranchia: Hydrobiidae) and notes on its life-cycle in Patagonia, Argentina. Systematic Parasitology, 63, 111-118.

Freije R.H., Marcovecchio J. 2004. Oceanografía química. In: (Eds. M.C. Piccolo and M.S. Hoffmeyer) Ecosistema del Estuario de Bahía Blanca. EDIUNS (UNS), Bahía Blanca, 69-78.

Gaillard M.C., Castellanos Z.J.A. de. 1976. Moluscos gasterópodos, Hydrobiidae. In: (Ed. R.A. Ringuelet) Fauna de Agua Dulce de la República Argentina (15), Fundación para la Educación, la Ciencia y la Cultura (FECIC), Buenos Aires, 1-39. 
Gibson, 2008. Family Renicolidae Dollfus, 1939. In: (Eds. R. A. Bray, D. I. Gibson and A. Jones) Keys to the Trematoda. Vol. 3. CABI Publishing and The Natural History Museum, Wallingford, 591-594.

Gilardoni C., Etchegoin J., Diaz J.I., Ituarte C., Cremonte F. 2011. A survey of larval digeneans in the commonest intertidal snails from Northern Patagonian coast, Argentina. Acta Parasitologica, 56, 163-179. DOI: 10.2478/s11686-011-0021-2.

Hechinger R.F. 2007. Annotated key to the trematode species infecting Batillaria attramentaria (Prosobranchia: Batillariidae) as a first intermediate host. Parasitology International, 56, 287 296. DOI:10.1016/j.parint.2007.06.004.

Jokela J., Lively C.M. 1995.Spatial variation in infection by digenetic trematodes in a population of freshwater snails (Potamopyrgus antipodarum). Oecologia, 103, 509-517.

Kostadinova A. 2005. Family Echinostomatidae Looss, 1899. In: (Eds. A. Jones, R.A. Bray and D.I. Gibson) Keys to the Trematoda. Vol. 2. CABI Publishing and The Natural History Museum, Wallingford, 9-64.

Kube J., Kube S., Dierschke V. 2002. Spatial and temporal variations of trematode infections in the mudsnail Hydrobia ventrosa in relation to the occurrence of waterfowl as definitive hosts. Journal of Parasitology, 88, 1075-1086.

La Sala L.F., Martorelli S.R., Alda P., Marcotegui P. 2009. Some digeneans from Olrog's gull Larus atlanticus Olrog, 1958 (Aves: Laridae) from the Bahía Blanca estuary, Argentina. Comparative Parasitology, 76, 113-116.

Lado P. 2011. Ciclo biológico de Dicrogaster fastigatus (Digenea: Haloporidae), parásito de la lisa (Mugil platanus) en la costa de Montevideo. Bs. thesis. Facultad de Veterinaria, Universidad de la República Montevideo, Uruguay.

Lafferty K.D., Sammond D.T., Kuris A.M. 1994. Analysis of larval trematode communities. Ecology, 75, 2275-85.

López Cazorla A. 2004. Peces. In: (Eds. M.C. Piccolo and M.S. Hoffmeyer) Ecosistema del Estuario de Bahía Blanca. EDIUNS (UNS), Bahía Blanca, 191-201.

Lunaschi L.I. 1985. Helmintos parasitos de peces de agua dulce de la Argentina IV. Acerca de la validez del género Plehniella Szidat, 1951 (Trematoda - Sanguinicolidae). Neotropica, 31, $149-154$.

Martin W.E. 1971. Larval stages of renicolid trematodes. Transactions of the American Microscopical Society, 90, 188-194.

Martin W.E. 1973. Life history of Saccocoelioides pearsoni n. sp. and the description of Lecithobotrys sprenti $\mathrm{n}$. sp. (Trematoda: Haploporidae). Transactions of the American Microscopical Society, 92, 80-95.

Martorelli S.R. 1986a. Estudios parasitológicos en biotopos lénticos de la República Argentina II: El ciclo biológico de Homalometron pseudopallidum sp. nov. (Digenea) parásito de Gymnogeophagus australis Eigenman, 1907 (Pisces, Cichlidae). Neotropica, 32, 3-12.

Martorelli S.R. 1986b. Estudios parasitológicos en biotopos lénticos de la República Argentina III: El ciclo biológico de Sacocoeloides carolae Lunaschi, 1985 (Digenea) parásito de Cichlaurus facetum Jenyns, 1842 (Pisces, Cichlidae). Neotropica, $32,125-132$.

Martorelli S.R. 1988. El ciclo biológico de Levinseniella cruzi Travassos, 1920 (Digenea, Microphallidae) parásita de los ciegos cólicos de Rollandia rolland chilensis (Aves, Podicipedidae) e Himantopus melanurus (Aves, Recurvirostridae). Iheringia, Série Zoologia, 68, 49-62.

Martorelli S.R. 1989. Estudios parasitológicos en la albufera de Mar Chiquita, provincia de Buenos Aires, República Argentina II: Cercarias (Digenea) parásitas de Heleobia conexa (Mollusca: Hydrobiidae), pertenecientes a las familias Schistosomatidae, Haploporidae y Homalometridae. Neotropica, 35, 81-90.
Martorelli S.R. 1990. Estudios parasitológicos en la albufera de Mar Chiquita, provincia de Buenos Aires, República Argentina. III Sobre dos cercarias parásitas de Heleobia conexa (Mollusca: Hydrobiidae) pertenecientes a la superfamilia Echinostomatoidea. Neotropica, 36, 55-63.

Martorelli S.R. 1991. El ciclo biológico abreviado de Microphallus simillimus (Travassos, 1920), comb. n. (Digenea: Microphallidae), parásito de Heleobia conexa (Molusca, Hydrobiidae) y de Himantopus melanurus (Aves, Recurvirostridae) en Argentina. Iheringia, Série Zoologia, 71, 91-98.

Martorelli S.R., Etchegoin J. 1996. Cercarias de la superfamilia Opistorchioidea en Heleobia conexa (Mollusca: Hydrobiidae) de la albufera de Mar Chiquita. Neotropica, 47, 61-67.

Martorelli S.R., Fredensborg B.L., Leung T.L.F., Poulin R. 2008. Four trematode cercariae from the New Zealand intertidal snail Zeacumantus subcarinatus (Batillariidae) New Zealand. Journal of Zoology, 35, 73-84. DOI: 0301-4223/08/3501-0073.

Martorelli S.R., Ivanov V. 1996. Host-induced and geographical variation in Levinseniella cruzi Travassos, 1920 (Digenea, Microphallidae). Proceedings of the Helminthological Society of Washington, 63, 130-135.

Martorelli S.R., Lino A., Marcotegui P., Montes M., Alda P., Panei C.J. 2012. Morphological and Molecular Identification of the Fish-Borne Metacercaria of Ascocotyle (Phagicola) longa Ransom, 1920 in Mugil liza from Argentina. Veterinary Parasitology, 190, 599-603. DOI: 10.1016/j.vetpar.2012.07.002.

Merlo M.J., Etchegoin J.A. 2010. Testing temporal stability of the larval digenean community in Heleobia conexa (Mollusca: Cochliopidae) and its possible use as an indicator of environmental fluctuations. Parasitology, 27, 1-8. DOI:10.1017/S00 31182010001150

Miller T.L, Cribb T.H. 2008. Family Cryptogonimidae Ward, 1917. In: (Eds. R. A. Bray, D. I. Gibson and A. Jones) Keys to the Trematoda. Vol. 3. CABI Publishing and The Natural History Museum, Wallingford, 51-112.

Olson P.D., Cribb T.H., Tkach V.V., Bray R.A., Littlewood D.T.J. 2003. Phylogeny and classification of the Digenea (Platyhelminthes: Trematoda). International Journal for Parasitology, 33, 733-755. DOI:10.1016/S0020-7519(03)00049-3.

Ostrowski de Núñez M. 1974. Fauna de agua dulce de la República Argentina. II. Cercaria perteneciente a la Superfamilia Opisthorchioidea y parte de su ciclo evolutivo (Trematoda). Physis Sección B, 33, 1-9.

Ostrowski de Núñez M. 1975. Fauna de agua dulce de la República Argentina. IV. Una cercaria de la familia Haploporidae (Trematoda). Neotropica, 21, 61-64.

Ostrowski de Núñez M. 1987. Der entwicklungszyklus von Acanthostomum brauni Mañe Garson und Gil, 1961 (Trematoda, Acanthostomatidae). Zoologische Anzeiger, 218, 273-286.

Ostrowski de Núñez M. 2001. Life cycles of two new sibling species of Ascocotyle (Ascocotyle) (Digenea, Heterophyidae) in the neotropical region. Acta Parasitologica, 46, 119-129.

Ostrowski de Núñez M. 2007. Life cycle of Stephanoprora uruguayense (Digenea: Echinostomatidae) in Argentina. Journal of Parasitology, 93, 1090-1096. DOI: 10.1645/GE1176R.1.

Ostrowski de Núñez M., Gil de Pertierra A. 1991. The life history of Acanthostomum gnerii Szidat, 1954 (Trematoda: Acanthostomidae), from the catfish Rhamdia sapo in Argentina. Zoologische Anzeiger, 277, 58-71.

Overstreet R.M., Curran S.S. 2005. Family Haploporidae Nicoll, 1914. In: (Eds. A. Jones, R. A. Bray and D. I. Gibson) Keys to the Trematoda. Vol. 2. CABI Publishing and The Natural History Museum, Wallingford, 129-165.

Petracci P.F., Delhey K. 2005. Guía de Aves Costeras y Marinas de la ría de Bahía Blanca. Editorial Universitaria de Buenos Aires SEM, Bahía Blanca, Argentina, 96 pp. 
Santos C.P., Lopes K.C., Costa V. da S., Santos E.G. 2013. Fish-borne trematodosis: potential risk of infection by Ascocotyle (Phagicola) longa (Heterophyidae). Veterinary Parasitology, 193, 302-306. DOI: 10.1016/j.vetpar.2012.12.011.

Schell S.C. 1970. How to know the Trematodes. W.C. Brown Company Publishers, Dubuque.

Scholz T., Pech-Ek M.C.F., Rodriguez-Canul R. 1995. Biology of Crassicutis cichlasomae, a parasite of cichlid fishes in Mexico and Central America. Journal of Helminthology, 69, 6975.

Shameem U., Madhavi R. 1991. Observations on the life-cycles of two haploporid trematodes, Carassotrema bengalense Rekharani and Madhavi 1985 and Saccocoelioides martini Madhavi, 1979. Systematic Parasitology, 20, 97-107.

Simões S.B.E., Barbosa H.S., Santos C.P. 2009. The life history of Pygidiopsis macrostomum Travassos, 1928 (Digenea: Heterophyidae). Memórias do Instituto Oswaldo Cruz, 104, 106111. DOI: 10.1590/S0074-02762009000100016.

Simões S.B.E, Barbosa H.S, Santos C.P. 2010. The life cycle of $A s-$ cocotyle (Phagicola) longa (Digenea: Heterophyidae), a causative agent of fishborne trematodosis. Acta Tropica, 113, 226-233. DOI: 10.1016/j.actatropica.2009.10.020.

Simões S.B.E., Neves R.F.C., Santos C.P. 2008. Life history of Acanthocollaritrema umbilicatum Travassos, Freitas and Bührnheim, 1965 (Digenea: Cryptogonimidae). Parasitology Research, 103, 523-528. DOI: 10.1007/s00436-008-1000-x.

Skirnisson K., Galaktionov K.V., Kozminsky E.V. 2004. Factors influencing the distribution of digenetic trematode infections in a mudsnail (Hydrobia ventrosa) population inhabiting salt marsh ponds in Iceland. The Journal of Parasitology, 90, 5059. DOI: http://dx.doi.org/10.1645/GE-118R

Stunkard H.W. 1964a. The morphology, life history and systematics of the digenetic trematode, Homalometron pallidum Stafford, 1904. Biological Bulletin, 126, 163-173.

Received: June 6, 2013

Revised: July 30, 2013

Accepted for publication: December 12, 2013
Stunkard H.W. 1964b. Studies on the trematode genus Renicola: observations on the life-history, specificity, and systematic position. Biological Bulletin, 126, 467-489.

Szidat L. 1951. Neue arten der trematodenfamilie Aporocotylidae aus dem blut and der leibeshöhle von süsswasser fischen des Río de La Plata. Zeitschrift für Parasitenkunde, 15, 70-86.

Szidat L. 1957. Über den Entwicklungszyklus von Psilochasmus oxyurus (Creplin, 1825) Lühe, 1910 (Trematoda, Psilostomidae) in Argentinien. Zeitschrift fur Parasitenkunde, 18, 2435 .

Szidat L. 1970. Saccocoelioides octavus n. sp., una nueva especie del género Saccocoelioides Szidat, 1954. Revista del Museo Argentino de Ciencias Naturales Bernardino Rivadavia, Zoología, 10, 87-100.

Szidat L., Szidat U. 1961. Die Trematoden der Gattung Notocotylus Diesing, 1839 (Notocotylidae Lühe, 1909) aus Südamerika bzw. Argentinien und Daten ihren Entwicklungsgeschichte. Zeitschrift fur Parasitenkunde, 21, 169-180.

Thieltges D.W., Ferguson M.A.D., Jones C.S., Noble L.R., Poulin R. 2009. Biogeographical patterns of marine larval trematode parasites in two intermediate snail hosts in Europe. Journal of Biogeography, 36, 1493-1501. DOI: 10.1111/j.13652699.2008.02066.x

Wilke T., Davis G.M., Falniowski A., Giusti F., Bodon M., Szarowska M. 2001. Molecular systematics of Hydrobiidae (Mollusca: Gastropoda: Rissooidea): testing monophyly and phylogenetic relationships. Proceedings of the Academy of Natural Sciences of Philadelphia, 151, 1-21. DOI: 10.1635/0097-3157(2001)151 [0001:MSOHMG]2.0.CO;2.

Yamaguti S. 1975. A synoptical review of life histories of digenetic trematodes of vertebrates. Tokyo: Keigaku Publishing Co. 